\title{
THE DORSAL SKINFOLD CHAMBER: WINDOW INTO THE DYNAMIC INTERACTION OF BIOMATERIALS WITH THEIR SURROUNDING HOST TISSUE
}

\author{
M.W. Laschke $e^{1,2,}$, B. Vollmar ${ }^{1,3}$ and M.D. Menger ${ }^{1,2}$ \\ ${ }^{1}$ Institute for Clinical and Experimental Surgery, University of Saarland, Homburg/Saar, Germany \\ ${ }^{2}$ Collaborative Research Center AO Foundation, University of Saarland, Homburg/Saar, Germany \\ ${ }^{3}$ Institute for Experimental Surgery, University of Rostock, Rostock, Germany
}

\begin{abstract}
The implantation of biomaterials into the human body has become an indispensable part of almost all fields of modern medicine. Accordingly, there is an increasing need for appropriate approaches, which can be used to evaluate the suitability of different biomaterials for distinct clinical indications. The dorsal skinfold chamber is a sophisticated experimental model, which has been proven to be extremely valuable for the systematic in vivo analysis of the dynamic interaction of small biomaterial implants with the surrounding host tissue in rats, hamsters and mice. By means of intravital fluorescence microscopy, this chronic model allows for repeated analyses of various cellular, molecular and microvascular mechanisms, which are involved in the early inflammatory and angiogenic host tissue response to biomaterials during the initial 2-3 weeks after implantation. Therefore, the dorsal skinfold chamber has been broadly used during the last two decades to assess the in vivo performance of prosthetic vascular grafts, metallic implants, surgical meshes, bone substitutes, scaffolds for tissue engineering, as well as for locally or systemically applied drug delivery systems. These studies have contributed to identify basic material properties determining the biocompatibility of the implants and vascular ingrowth into their surface or internal structures. Thus, the dorsal skinfold chamber model does not only provide deep insights into the complex interactions of biomaterials with the surrounding soft tissues of the host but also represents an important tool for the future development of novel biomaterials aiming at an optimisation of their biofunctionality in clinical practice.
\end{abstract}

Keywords: Dorsal skinfold chamber, biomaterials, inflammation, angiogenesis, intravital fluorescence microscopy, in vivo, implantation, tissue engineering.

\author{
*Address for correspondence: \\ Matthias W. Laschke \\ Institute for Clinical and Experimental Surgery \\ University of Saarland \\ D-66421 Homburg/Saar, Germany
}

Telephone Number: +496841 1626554

FAX Number: +496841 1626553

E-mail: matthias.laschke@uks.eu

\section{Introduction}

Recent progress in the fields of material science, biotechnology and tissue engineering has resulted in a tremendous increase in the introduction of different biomaterial devices in pharmacy and medicine. These include drug delivery systems (Svirskis et al., 2010), metallic implants (Ryan et al., 2006), prosthetic vascular grafts (Roll et al., 2008), bone and cartilage substitutes (Busenlechner et al., 2008; Berghaus et al., 2010), synthetic surgical meshes (Shankaran et al., 2011) and scaffolds for the engineering of artificial tissues (Kim et al., 2010). However, a riskless and successful use of such devices in clinical practice is only possible, if they exhibit an adequate biocompatibility. This means that they should not induce a severe local or systemic inflammatory reaction. On the other hand, they should exhibit an optimal biofunctionality, i.e., the ability to perform the specific task for which they are intended (Morais et al., 2010). For the development of novel devices fulfilling these preconditions there is an increasing need for appropriate technologies and assays, which allow for the systematic evaluation of the interaction of implanted biomaterials with the host tissue.

This interaction is a highly dynamic process, which is subsumed under the term 'foreign body reaction' and comprises distinct steps (Anderson et al., 2008). Immediately after implantation into the body, a layer of adsorbed host proteins forms onto the surface of a biomaterial, which critically influences the subsequent cellular reaction to the implant (Gray, 2004; Thevenot et al., 2008). In the acute phase, this reaction is characterised by the activation of leukocytes, which infiltrate the implantation site and produce various cytokines and growth factors (Keselowsky et al., 2007; Velard et al., 2010). Moreover, monocytes are recruited from the blood stream and start to differentiate into macrophages (Kou and Babensee, 2011). Persistent inflammatory stimuli may result in a chronic foreign body reaction. This is associated with the accumulation of lymphocytes and fusion of individual macrophages to multinucleated giant cells, which are typically found at the interface between the implanted biomaterial and the surrounding host tissue (Xia and Triffitt, 2006). In addition, fibroblast proliferation and migration as well as development of new blood vessels results in the formation of a vascularised granulation tissue or a fibrous capsule around the implant, determining its final incorporation at the implantation site (Morais et al., 2010).

Because a foreign body reaction involves a broad range of different cell types, cytokines and growth factors, it is 

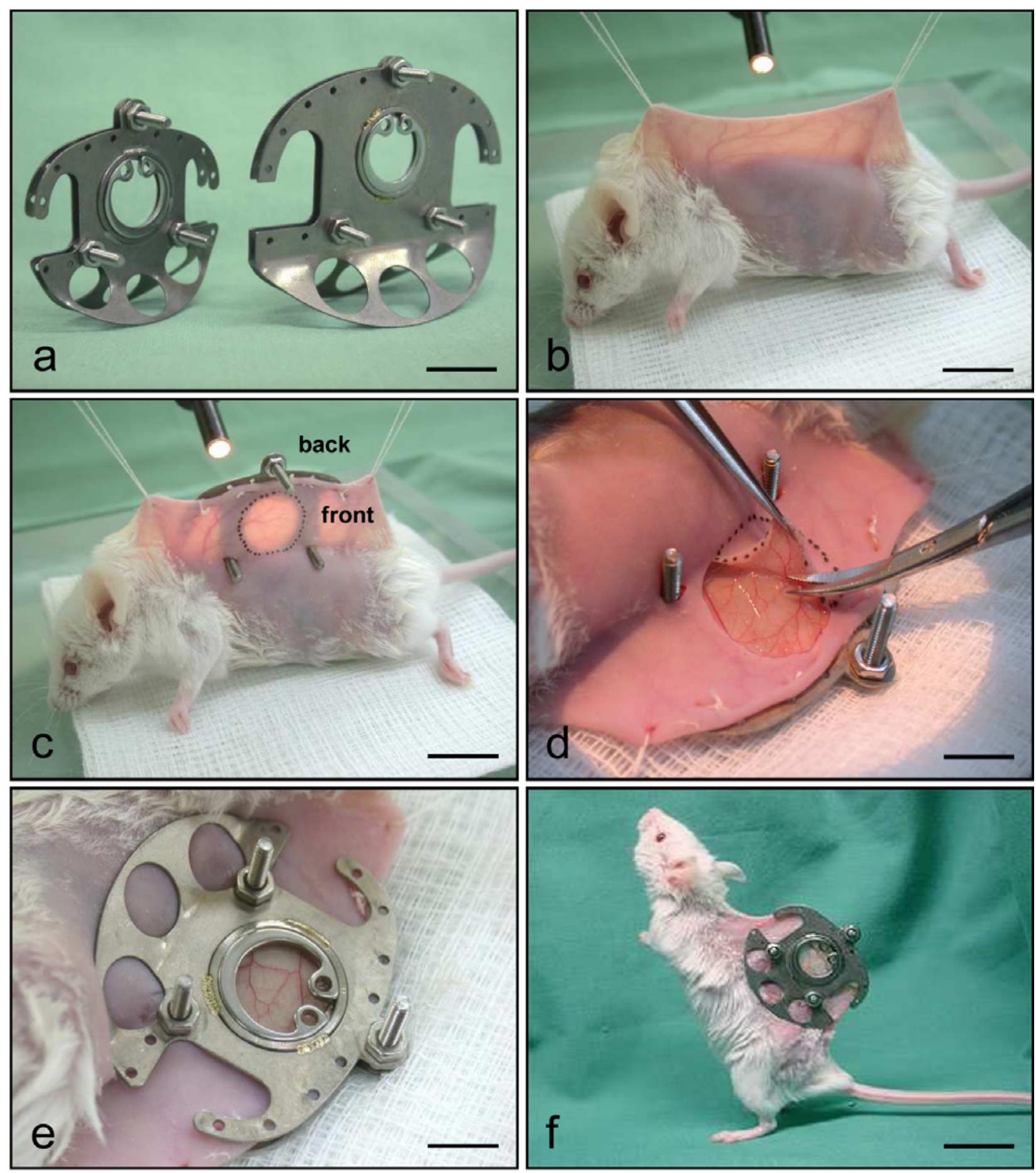

Fig. 1. (a) Window chambers consisting of two symmetrical titanium frames for insertion into the dorsal skinfold of mice (chamber on the left side, weight: $\sim 2 \mathrm{~g}$ ) and Syrian hamsters or rats (chamber on the right side, weight: $\sim 4 \mathrm{~g}$ ). (b-e) Stepwise preparation of a dorsal skinfold chamber in an anaesthetised balb/c mouse. (f) The animal tolerates the chamber well, as indicated by normal orientation behaviour. Scale bars: $(\mathbf{a})=14 \mathrm{~mm} ;(\mathbf{b}, \mathbf{c})=16 \mathrm{~mm} ;(\mathbf{d}, \mathbf{e})=$ $8 \mathrm{~mm}$; (f) $=19 \mathrm{~mm}$.

not possible to simulate adequately this complex process under in vitro conditions or via computer. Accordingly, the in vivo analysis of biomaterials by means of sophisticated animal models represents an essential prerequisite for the successful development of novel biomedical devices and their establishment into clinical practice. In the following, this review will focus on the dorsal skinfold chamber model. By means of intravital fluorescence microscopy, this chronic model has been broadly used during the last two decades for the repetitive in vivo analysis of various biomaterials and, thus, has provided deep insights into the mechanisms regulating the angiogenic and inflammatory host tissue response to implanted biomaterials (Menger et al., 1990a; Kraft et al., 2000; Laschke et al., 2005a; Rücker et al., 2006; Laschke et al., 2007; Wieghaus et al., 2008). 


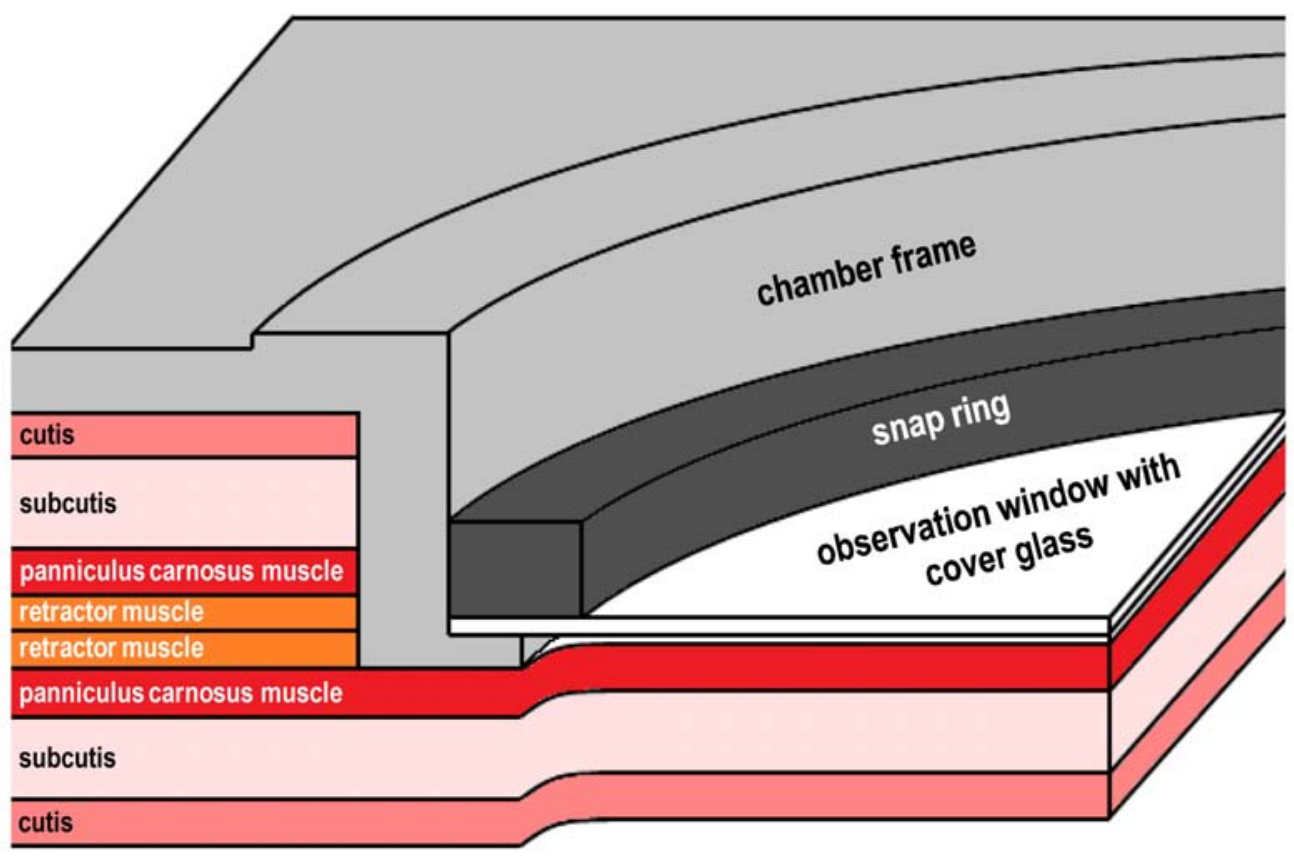

Fig. 2. Schematic drawing showing the different tissue layers of the skinfold, which are included in the observation window of the chamber, i.e. panniculus carnosus muscle, subcutis and cutis. These layers are covered with a removable cover glass incorporated into one of the chamber frames.

\section{Preparation of the dorsal skinfold chamber and biomaterial implantation}

For the preparation of the dorsal skinfold chamber, which consists of two symmetrical frames (Fig. 1a), animals should have a body weight ranging between $22-25 \mathrm{~g}$ in mice, $60-80 \mathrm{~g}$ in hamsters and 150-200 $\mathrm{g}$ in rats. The back of the anaesthetised animals is carefully shaven and chemically depilated avoiding micro-injuries to the skin. Subsequently, the hair-free back is cleaned under $37^{\circ} \mathrm{C}$ warm water ensuring a complete removal of the depilatory cream, which may otherwise induce inflammatory irritations. Then, the animals are put in prone position and the back is exposed to medical disinfectant spray. The skinfold of the animals is extended and examined under transillumination in order to position the major feeding and draining blood vessels congruently. The sandwiched skinfold is then cranially and caudally affixed at midline with two 5-0 silk sutures (Fig. 1b). The first chamber frame is fixed by 5-0 silk sutures on its superior edge to the back side of the skinfold and two openings are carefully prepared at the base of the skinfold that is close to the body, through which the connecting screws are passed from the back to the front side (Fig. 1c). After marking the circular area of the later observation window, the animals are placed in lateral position under a stereo-microscope. By means of microsurgical instruments, one layer of skin and subcutis with the panniculus carnosus muscle as well as the two layers of the retractor muscle are completely removed within this area (Figs. 1d and 2). Thereby it is of major importance that the size of the removed area $(\sim 15$ $\mathrm{mm}$ in diameter) exceeds the diameter of the observation window $(\sim 11 \mathrm{~mm})$ to avoid tissue compression after positioning the second chamber frame. Moreover, special care should be taken during the removal of the second layer of retractor muscle, because it is in direct contact to the underlying panniculus carnosus muscle, which serves for later microscopic analyses and, thus, should not be damaged. Subsequently, the second frame of the chamber is put on the connecting screws with a frame-toframe distance of 400-500 $\mu \mathrm{m}$ using stainless steel nuts as spacers to prevent compression of both the supplying arterioles and the draining venules of the chamber. During the entire chamber implantation procedure, the operation field is kept moist with $37^{\circ} \mathrm{C}$ physiological saline to avoid drying of the tissue. Finally, the chamber preparation is hermetically closed by placing a cover glass in the observation window of the second frame, which is fixed by means of a snap ring and provides direct microscopic access to the microcirculation of the chamber (Fig. 1e). After the preparation, which takes not longer than 20-30 min for a trained person, the animals should recover for at least $48 \mathrm{~h}$ before implantation of biomaterials in order to exclude deterioration of the microcirculation due to the anaesthesia and the surgical trauma of the preparation procedure. The animals tolerate the chambers well, as indicated by normal daily feeding, cleaning and sleeping habits, which do not differ from those of animals without chambers (Fig. 1f).

For the in vivo analysis in the dorsal skinfold chamber, the implanted biomaterials should not be thicker than 1 $\mathrm{mm}$ to guarantee the closure of the chamber free from air. Moreover, the biomaterials should not substantially exceed a size of $\sim 3 \times 3 \mathrm{~mm}$ to enable analyses of the border zones in direct vicinity to the implants as well as of distant areas within the chamber, which may serve as control 
tissue that is not affected by the implanted biomaterials. Thus, biomaterial implants, of which many are quite big in size for clinical applications, cannot be tested in their original size. However, this does not necessarily represent a disadvantage for the analysis of the angiogenic and inflammatory host tissue response at the implantation site. In fact, the testing of small biomaterial implants of identical size bears the advantage that the biocompatibility of these implants is directly comparable under the standardised conditions of the dorsal skinfold chamber model.

For implantation of a biomaterial, the cover glass of the chamber is temporarily removed and the biomaterial is freely positioned onto the panniculus carnosus muscle taking care to avoid contamination, mechanical irritation or damage of the prepared tissue. Due to this mode of implantation, there is no mechanical loading of the biomaterial. However, mechanical stress has been shown to be a crucial determinant for the angiogenic activation and differentiation of stem cells (Kasper et al., 2007; Glaeser et al., 2010) and, thus, may in particular affect the vascularisation of stem cell-seeded biomaterials, such as scaffolds for tissue engineering (Sandino et al., 2010).

To overcome the disadvantage that the mechanical environment is completely excluded in the chamber model, static mechanical load can be applied to biomaterial implants by pressing a silicone pad, which is fixed with an adjustable screw to one of the chamber frames, on the cutis of the back side of the observation window (Becker et al., 1994; Schäfer et al., 2005; Contaldo et al., 2007). The combination of this technical modification with a micromotor may in future studies even allow exposing biomaterial implants to dynamic mechanical stresses over prolonged time periods.

\section{Characteristics of the dorsal skinfold chamber model}

The classical experimental approach to study biocompatibility, vascularisation and tissue incorporation of biomaterials is their implantation into a subcutaneous pocket. In this case, data are normally based on histological and immunohistochemical analyses of isolated biomaterial samples at a single observation time point. In contrast, the dorsal skinfold chamber is a chronic in vivo model, which allows for the non-invasive and repetitive analysis of the angiogenic and inflammatory host tissue response to implanted biomaterials in individual animals over time by means of intravital microscopy, as discussed in detail below. This maximises the amount of data obtained from each animal and, by this, limits the statistical variability and reduces the number of animals required for a study. Moreover, in contrast to histological and immunohistochemical analyses, intravital microscopic measurements in the dorsal skinfold chamber are performed in living animals, which enables the qualitative and quantitative assessment of functional parameters such as vessel growth, microvascular perfusion, vascular permeability and cellular interactions with a high spatial and temporal resolution. For this purpose, the microscopic images are stored on videotape, DVD or hard disc for the subsequent analysis by means of a computer-assisted offline analysis system.
The dorsal skinfold chamber model is based on different chamber techniques, which have been introduced in rabbits and mice during the last century to study the growth and behaviour of living cells and tumour implants by intravital microscopy (Sandison, 1928; Algire, 1943; Arfors et al., 1970). The basic principle of this model is to provide a chronic access to exposed tissues in an implanted chamber for microscopic imaging through an observation window. In case of the dorsal skinfold these tissues comprise striated muscle, i.e., the panniculus carnosus, subcutis and skin.

To enable analyses under physiological conditions, animals are usually allowed to recover for 2-3 days from the surgical trauma of the chamber implantation before starting the experiments. Moreover, it is necessary that the tissues inside the chamber are not affected by the implanted chamber material itself. Therefore, chambers originally consisted of aluminium, which was covered with Teflon $\mathrm{S}$ to guarantee low weight, low thermal conductivity and biological inertness (Endrich et al., 1980). Nowadays, the chambers are usually made of titanium, which also exhibits these material properties and additionally provides an improved stability (Menger et al., 2002). Besides, nonmetallic chambers composed of polymer materials have been fabricated, which can be applied to studies employing ionising or non-ionising radiation in animal exposure experiments without inducing thermal effects (Ushiyama et al., 2004). Moreover, they are compatible for magnetic resonance imaging (MRI) (Gaustad et al., 2008; Erten et al., 2010).

The dorsal skinfold chamber model has been established in rats (Papenfuss et al., 1979), immuno-competent mice (Cardon et al., 1970), nude and severe combined immunodeficient mice (Leunig et al., 1992; Lehr et al., 1993) as well as in hamsters (Endrich et al., 1980). In contrast to rats and mice, preparation of the dorsal skinfold chamber in hamsters bears the major advantage that the retractor muscle is only loosely attached to the underlying panniculus carnosus muscle without many vascular interconnections between the two muscle layers. Accordingly, the retractor muscle can easily be removed without surgical trauma to the tissue, which serves for later microscopic analyses. Moreover, the hamster dorsal skinfold preparation is characterised by a better translucency due to a thinner panniculus carnosus muscle, resulting in an improved microscopic image quality when compared to the mouse or rat chamber. On the other hand, the mouse as experimental animal is less expensive and genetically better defined than the hamster. In addition, there is a multitude of knock-out and transgenic strains, which allow for the analysis of physiological and pathological processes on a molecular basis. The availability of a broad range of monoclonal antibodies directed against distinct cell surface molecules further enables for detailed immunohistochemical analyses of isolated tissue samples. For these reasons, biomaterial studies in the dorsal skinfold chamber model are increasingly performed in mice.

The dorsal skinfold chamber can easily be positioned under an upright microscope for intravital microscopic analyses of the microcirculation (Figs. 3a-d). For this purpose, the animal has to be fixed on a stage, which allows for horizontal positioning of the observation window under 

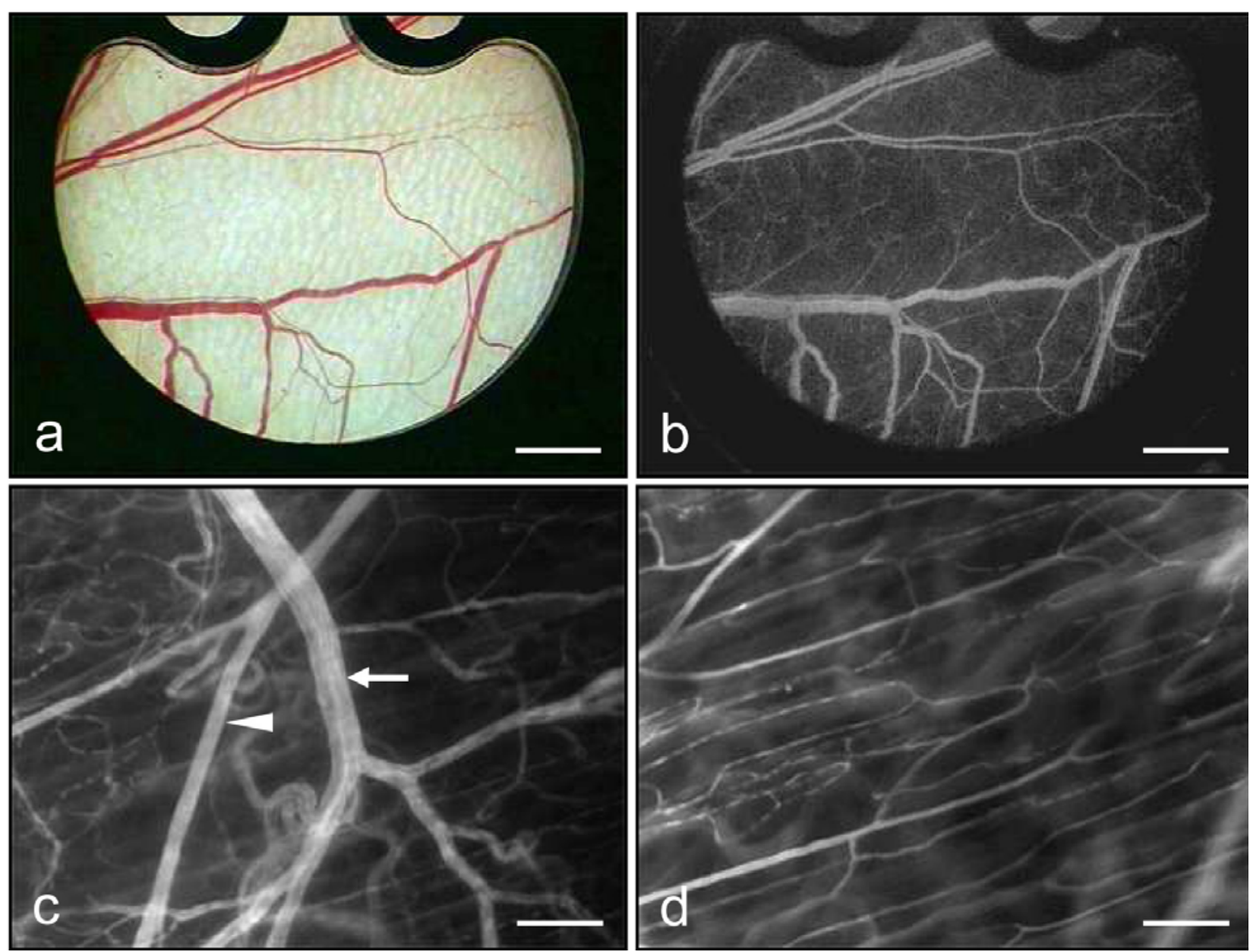

Fig. 3. (a, b) Intravital overview of the observation window of a mouse dorsal skinfold chamber as documented (a) by transillumination and (b) by fluorescence epi-illumination microscopy (blue light with intravascular plasma contrast enhancement by $5 \%$ FITC-labelled dextran $(150 \mathrm{kDa})$ i.v. $)$. (c, d) Fluorescence microscopic view of the micro-angioarchitecture in the chamber showing an arteriole (arrowhead in c), a collecting venule (arrow in c) and a parallel arrangement of muscle capillaries (d). Scale bars: (a, b) $=1.7 \mathrm{~mm}$; (c) $=170 \mu \mathrm{m}$; (d) $=85 \mu \mathrm{m}$.

the microscope objectives. In principle, microscopy of the chamber is possible by means of long distance objectives or water and oil immersion objectives, because the snap ring and surrounding frame form a convenient space for fluids. However, ideal objectives should exhibit a narrow, tapered shape and a long working distance. This allows the microscopic examination of the entire observation window. When using large objectives with a small working distance, microscopic examination of the margins of the observation window may not be possible due to collision with the snap ring or the connecting screws of the chamber frames.

Intravital microscopic analyses are repetitively performed over an observation period that is not longer than 2-3 weeks, because the elasticity of the dorsal skinfold decreases over time. This can lead to tilting of the chamber, which may affect the perfusion of the prepared tissue. Accordingly, the dorsal skinfold chamber model is typically used to analyse the early inflammatory and angiogenic host tissue response to implanted biomaterials rather than the chronic foreign body reaction. Although this may represent a disadvantage of this model, it has to be considered that this early observation period may be of particular interest in biomaterial testing, because especially the initial vascularisation of implants has been proposed to be a crucial determinant for adequate biomaterial incorporation into the host tissue, minimising the risk of extrusion, migration and infection (Sclafani et al., 1997; Naik et al., 2007).

Using the dorsal skinfold chamber model in combination with transillumination microscopy techniques, it is possible to assess parameters of vascularisation such as microvessel diameter, density and blood flow. Even more versatile analyses of cellular and molecular aspects can be done by means of epi-illumination fluorescence microscopy. For this purpose, different fluorescent dyes are injected intravenously via a jugular catheter or directly into the tail vein or retrobulbary space. For instance, fluorescein isothiocyanate (FITC)-labelled dextran with a molecular weight of $150 \mathrm{kDa}$ or albumin is applied for contrast enhancement of individual microvessels by intravascular staining of plasma. Because of their high molecular weight, these fluorescence markers only extravasate in case of disturbed endothelial integrity and, thus, can be used for the analysis of vascular leakage during inflammatory or 

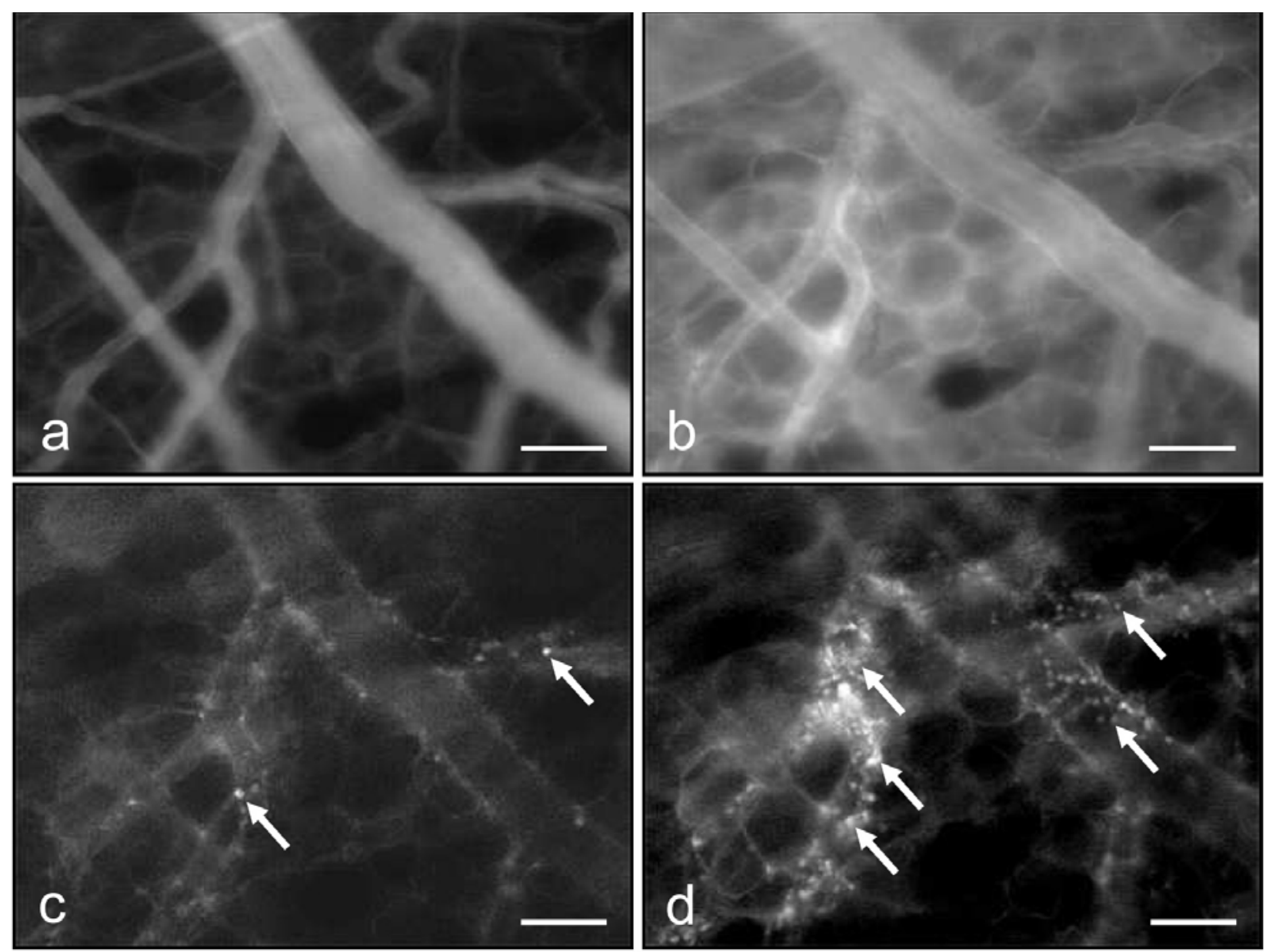

Fig. 4. Intravital fluorescence microscopy of postcapillary and collecting venules of a dorsal skinfold chamber (a, b) Blue light epi-illumination with intravascular plasma contrast enhancement by $5 \%$ FITC-labelled dextran $(150 \mathrm{kDa})$ i.v.; (c, d) Green light epi-illumination for visualisation of rhodamine 6G-stained leukocytes) under physiological conditions (a, c) and $2 \mathrm{~h}$ after induction of inflammation by topical administration of tumour necrosis factor (TNF)- $\alpha$ (b, d). (a, b) Inflammation is typically associated with extravasation of the contrast medium, as indicated by increased brightening of the tissue of panel b when compared to that of panel a. (c, d) TNF- $\alpha$-treatment also causes massive accumulation of rhodamine 6G-stained leukocytes (c, d, arrows), apparently interacting with the endothelium. Scale bars: $85 \mu \mathrm{m}$.

angiogenic processes (Menger et al., 1992a) (Figs. 4a and b). To study the interaction of leukocytes and platelets with the microvascular endothelium, the cells can be stained in situ with rhodamine 6G (Baatz et al., 1995) (Figs. 4c and $\mathrm{d}$ ). In addition, individual necrotic cell death can be detected by the use of propidium-iodide (Harris et al., 1997), whereas apoptotic cells can be identified by nuclear condensation, margination and fragmentation following local bisbenzimide staining (Vollmar et al., 2001).

Besides conventional epi-illumination fluorescence microscopy, imaging in the dorsal skinfold chamber model has increasingly been performed in recent years by means of confocal microscopy techniques (Isaka et al., 2004; Makale, 2007; Strieth et al., 2008). Using a pinhole aperture for point illumination, single-photon laser-scanning microscopy allows the detection of light from a specific volume within the plane of focus, so that the resultant image is comparatively free of scattered light and attendant blurring (Makale, 2007). Accordingly, the obtained microscopic images exhibit an improved optical resolution and contrast. Moreover, it is possible to concatenate individual optical sections to create a threedimensional reconstruction of the object of interest. As a variation of this technique, multiphoton microscopy uses near-infrared lasers for two-photon excitation, which allows the generation of bright, high-resolution images in sample depths of 500-1000 $\mu \mathrm{m}$, while photobleaching and phototoxicity-induced tissue damage is markedly reduced (Makale, 2007; Ishii and Ishii, 2011).

In addition to microscopy, several other non-invasive techniques have been used in the past for the analysis of microcirculatory parameters within the dorsal skinfold chamber, including Laser Doppler flowmetry for the assessment of microvascular tissue perfusion (Menger et al., 1992b) or phosphorescence quenching for the measurement of tissue oxygenation (Kerger et al., 1996). However, these techniques are indirect in nature and, thus, do not allow for the direct visualisation of distinct cellular 
mechanisms, such as the interaction of leukocytes with the microvascular endothelium or the ingrowth of new blood vessels into implanted biomaterials.

\section{Biomaterial research in the dorsal skinfold chamber model}

During the last two decades, many experimental studies have been performed using the dorsal skinfold chamber model to study the inflammatory and angiogenic host tissue response to various biomaterials. These include prosthetic vascular grafts, metallic implants, surgical meshes, bone substitutes, scaffolds for tissue engineering as well as locally or systemically applied drug delivery systems (Figs. $5 \mathrm{a}-\mathrm{c})$. The following chapters provide an overview of these studies and highlight the most interesting conclusions, which can be drawn from their findings.

\section{Prosthetic vascular grafts}

Implantation of prosthetic vascular grafts for both replacement and bypass procedures represents a central therapeutic approach in the field of cardiovascular surgery. However, this approach bears the risk of early graft failure due to infection (Chiesa et al., 2002; Zetrenne et al., 2007; Herscu and Wilson, 2009) or thrombotic occlusion (Kraiss and Johansen, 1995; Bonhomme et al., 2010). A major prerequisite for the prevention of these serious complications is a rapid and adequate vascularisation of the vascular prostheses during the early healing process. In fact, insufficient graft vascularisation contributes to a poor incorporation of the implant into the surrounding host tissue, which may result in perigraft seroma formation and subsequent infection (Borrero and Doscher, 1988). Moreover, deficient transmural ingrowth of newly formed microvessels may cause thrombotic graft occlusion due to an impaired development of neointimal coverage (Rahlf et al., 1986). For these reasons, it is of major importance to identify material properties, which promote the early vascularisation of the implanted prosthetic vascular graft material.

The most frequently used materials for the fabrication of prosthetic vascular grafts are polytetrafluorethylene (PTFE) and polyethylenterephtalate (Dacron). After implantation of these materials into the dorsal skinfold chamber of Syrian golden hamsters it could be demonstrated that Dacron grafts, which exhibit a high porosity with an internodal distance of $212 \mu \mathrm{m}$, induce a strong angiogenic host tissue response with the development of dense microvascular networks and a large number of capillaries piercing into the interstices of the implants (Menger et al., 1990a). In contrast, transmural capillary ingrowth cannot be observed in the less porous PTFE grafts with an internodal distance ranging between 1-30 $\mu \mathrm{m}$ (Menger et al., 1990a,b). By measuring the dynamic breaking strength, i.e. the force necessary to remove the grafts from the host tissue within the chamber, it could further be shown that the extent of graft vascularisation positively correlates with the integration of the materials into the perigraft tissue (Menger et al., 1990a,b). Taken together,
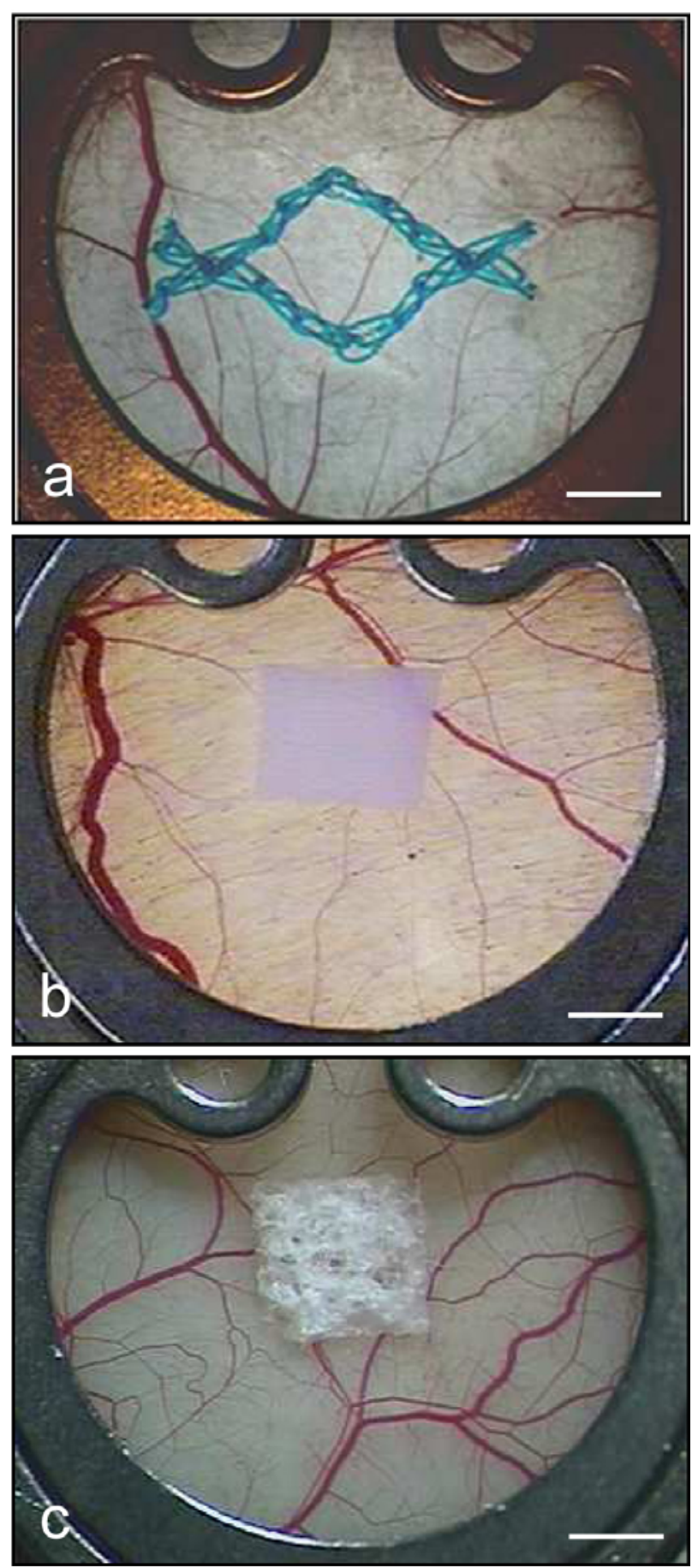

Fig. 5. Overview of the observation window of a hamster (a, b) and a mouse dorsal skinfold chamber (c) directly after implantation of the surgical mesh Ultrapro $^{\circledR}$ (a), the synthetic bone substitute Ostim ${ }^{\circledR}$ (b) and a porous polyurethane scaffold for tissue engineering (c). Scale bars: $1.6 \mathrm{~mm}$.

these findings clearly indicate that synthetic implants can be optimised for different applications by modification of their porosity. Porous implants should be preferred for vascular prostheses, whereas dense materials with a low porosity, such as PTFE with an internodal distance of 1 $\mu \mathrm{m}$, may be more useful for the replacement of biological membranes, such as pericardium or peritoneum (Menger et al., 1990b). 
Besides fully synthetic materials, biosynthetic and biological materials are used for the fabrication of vascular prostheses, because they are supposed to offer improved surgical handling characteristics and healing conditions. Biosynthetic composite grafts consisting of ovine collagen and polyester $\left(\mathrm{Omniflow}^{\circledR}\right)$ have shown an early vascularisation and tight incorporation into the surrounding chamber tissue (Menger et al., 1992c). Of interest, this has not been the case for biolised bovine artery grafts $\left(\right.$ SolcoP $\left.{ }^{\circledR}\right)$, which may be due to the formation of a fibrous collagen capsule around the implants (Menger et al., 1992c). In a recent study, Esguerra et al. (2010) used the dorsal skinfold chamber model to analyse the in vivo vascularisation and biocompatibility of bacterial cellulose as a potential novel biomaterial for the reconstruction of small-diameter blood vessels. Bacterial cellulose is a three-dimensional asymmetric hydrogel-like structure configured as a microfibril network, which is produced by the bacterium Acetobacter xylinum (Brown et al., 1976). Although bacterial cellulose lacks a defined pore size, it exhibits a porosity of $>90 \%$ (Esguerra et al., 2010). Moreover, it is possible to generate tubes of bacterial cellulose with mechanical properties that are adequate for vascular grafts (Bodin et al., 2007). Of interest, it was found that bacterial cellulose exhibits a biocompatibility, which is comparable to that of PTFE and polyglycolid acid (PGA) implants (Esguerra et al., 2010). Nonetheless, because bacterial cellulose only induces a poor angiogenic host tissue response during the first 14 days after implantation into the dorsal skinfold chamber, further long-term studies have to clarify the suitability of this biological material for the fabrication of vascular prostheses, which are adequately incorporated into the surrounding host tissue.

\section{Metallic implants}

Various metallic implants are commercially available for osteosynthesis in traumatology and orthopaedic surgery. Their majority is based on titanium and stainless steel due to the mechanical properties of these materials. Because metallic implants are in direct contact with the soft tissue at the implantation site, the dorsal skinfold chamber consisting of striated muscle tissue, subcutis and cutis is an ideal model to study their effects on the local microcirculation under in vivo conditions. Using this model, Kraft et al. (2000) demonstrated that titanium only induces a transient up-regulation of leukocyte-endothelial cell interactions in venules of the host tissue during the first $24 \mathrm{~h}$ after implantation, indicating a high degree of biocompatibility. This is also the case for commonly used titanium alloys, such as titanium-aluminium-vanadium (Ti-6Al-4V), titanium-aluminium-niobium (Ti-6Al-7Nb) and titaniummolybdenum (Ti-15Mo) (Kraft et al., 2005; Pennekamp et al., 2006, 2007). Furthermore, modification of titanium implants by plasma pre-treatment and collagen I coating contributes not only to a reduced foreign body reaction but also enhances angiogenesis at the implantation site (Hauser et al., 2009). In contrast, implants made of silver induce a permanent breakdown of the microcirculation with a massive increase of vascular leakage and extravasation of leukocytes 3 days after implantation into the dorsal skinfold chamber (Kraft et al., 2000). This should be considered in situations, where silver-coated implants are recommended due to their antimicrobial properties (Monteiro et al., 2009). Stainless steel implants also provoke an inflammatory host tissue reaction, which, however, is only moderate and of temporary nature. Studies could show that this reaction can be reduced by using stainless steel alloys containing less amounts of nickel (Kraft et al., 2001a) or by sol-gel calcium phosphate coating of the material (Kraft et al., 2002).

After implantation of metallic devices, wear particles may detach from their surface and accumulate in the surrounding tissues. The biocompatibility of these fretting particles may differ significantly from that of the bulk implants, because their composition can deviate due to tribochemical reactions or corrosion (Jacobs et al., 1998). Based on these considerations, wear particles produced from stainless steel or titanium were analysed in the hamster dorsal skinfold chamber and compared to the corresponding bulk implants (Kraft et al., 2001b; Kraft et al., 2003). By this, no marked differences could be found between titanium bulk and debris. However, stainless steel wear debris induces a massively increased inflammatory reaction with oedema formation and breakdown of the microcirculation within $24 \mathrm{~h}$ after implantation when compared to bulk stainless steel. This may be explained by the increased release of nickel and chromium from the wear particles, indicating that not only the bulk properties of metallic devices but also the microcirculatory implications of inevitable wear debris play a crucial role in determining the implants' biocompatibility (Kraft et al., 2001b; Kraft et al., 2003).

\section{Surgical meshes}

Hernia repair represents one of the most frequent operations in general surgery (Rutkow, 2003). Meanwhile, implantation of surgical meshes has become the golden standard in hernia surgery. The major advantage of this procedure is a tension-free repair of the abdominal wall defect, resulting in reduced post-operative pain and significantly decreased recurrence rates of less than $20 \%$ when compared to conventional suture closures (Luijendijk et al., 2000; Burger et al., 2004). However, implantation of surgical meshes also bears the risk of infection, adhesions, and seroma or fistula formation (Robinson et al., 2005; Jezupovs and Mihelsons, 2006). Accordingly, one major challenge in modern hernia repair is the development of novel surgical mesh materials, which exhibit an optimal biocompatibility and which are adequately integrated into the surrounding host tissue. For these reasons, the dorsal skinfold chamber has been introduced as a model, which allows for the first time the repetitive in vivo analysis of inflammatory effects, vascularisation and incorporation of different surgical mesh materials (Laschke et al., 2005a).

Prolene $^{\circledR}$, Ultrapro ${ }^{\circledR}$ and Vicryl ${ }^{\circledR}$ meshes are commonly used meshes, which differ in polymer composition, mesh architecture and resorbability. After their implantation into the hamster dorsal skinfold chamber, it was found that the multifilament Vicryl ${ }^{\circledR}$ mesh induces a more pronounced angiogenic and inflammatory host tissue response when compared to the monofilament Prolene ${ }^{\circledR}$ 
and Ultrapro ${ }^{\circledR}$ mesh (Laschke et al., 2009a). However, this is not associated with an improved material incorporation. In fact, the granulation tissue surrounding the Vicryl ${ }^{\mathbb{R}}$ mesh is instable due to low collagen content and massive infiltration of histiocytes, multinucleated giant cells and polymorphonuclear granulocytes (Laschke et al., 2009a). These results indicate that a stronger angiogenic and inflammatory response to an implanted surgical mesh does not necessarily result in a better incorporation into the host tissue.

Based on the finding that immunosuppressive therapy affects angiogenesis and collagen synthesis during wound healing (Kelley et al., 1990; Schäffer et al., 2007), a recent study analysed, how the immunosuppressive drugs rapamycin and cyclosporine $\mathrm{A}$ influence the incorporation of Ultrapro ${ }^{\circledR}$ meshes (Laschke et al., 2009b). This is an issue of major clinical relevance, considering the fact that the incidence of incisional hernias following orthotopic liver transplantation has markedly increased during the last ten years (Kahn et al., 2007). Interestingly, rapamycin dosedependently inhibits the ingrowth of new microvessels from the host striated muscle tissue of the chamber into the meshes, resulting in a significantly decreased microvessel density at the implantation site when compared to cyclosporine A-treated and non-treated control animals (Laschke et al., 2009b). This is associated with a reduced collagen content of the newly formed granulation tissue around the implants. Accordingly, immunosuppressed patients should not receive rapamycin in case of incisional hernia repair to guarantee optimal mesh incorporation.

A severe complication of surgical mesh implantation is bacterial infection. Using the dorsal skinfold chamber model in combination with intravital fluorescence microscopy it is possible to study in vivo the interaction of bacteria with the microvascular endothelium (Laschke et al., 2005b; Kerdudou et al., 2006). Roller et al. (2008) injected FITC-labelled Staphylococcus aureus into Syrian golden hamsters, which were equipped with dorsal skinfold chambers containing Ultrapro ${ }^{\circledR}$ meshes and analysed the adherence of the circulating bacteria in microvessels surrounding the implants. This study could demonstrate that Ultrapro ${ }^{\circledR}$ meshes do not increase the adherence of bacteria in microvessels at the implantation site under physiological conditions as well as under tumour necrosis factor (TNF)- $\alpha$-induced local inflammation. Therefore, Ultrapro $^{\circledR}$ meshes cannot be considered as an important trigger for an increased bacteria-endothelial cell interaction, which leads to the conclusion that this mechanism seems not to play a major role in the development of late-onset Ultrapro $^{\circledR}$ mesh infections.

\section{Bone substitutes}

For the reconstruction of bone defects due to fractures, non-unions or resection of benign tumours and bone cysts, transplantation of autologous bone is still considered the golden standard in bone repair, because it guarantees optimal osteogenesis, osteoinduction and osteoconduction (Giannoudis et al., 2005). However, this approach bears the disadvantage of a prolonged overall surgical procedure and anaesthesia time with all its risks. Moreover, harvesting of bone autografts from the iliac crest can be associated with local complications, such as nerve injury or infection (Seiler and Johnson, 2000). Alternatively, thermodisinfected and cryopreserved allogenic bone graft substitutes may be used. Recently, Ring et al. (2011a) implanted chips consisting of dehydrated human femoral head into dorsal skinfold chambers of balb/c mice and found that surface activation with glow discharge gas plasma accelerates and improves their vascularisation without inducing adverse effects in the host microcirculation. These promising findings indicate that this novel technology may be used in the future to increase the incorporation rates of clinically applied allogeneic bone implants.

Most of the commercially available synthetic bone substitutes are chemically based on calcium phosphate compounds. These include the granulated ceramics Algipore $^{\circledR}$, BioOss $^{\circledR}$, ChronOs $^{\circledR}$ and Endobon ${ }^{\circledR}$, as well as the absorbable bone cements Calcibon ${ }^{\circledR}$, Biobon ${ }^{\circledR}$ and Norian SRS ${ }^{\circledR}$. Of interest, Roetman et al. (2010) showed that all of these biomaterials induce a comparable host tissue response in the chamber model, excluding material-specific reasons for the reported sporadic failure of these bone substitutes in clinical practice. NanoBone ${ }^{\circledR}$ and Ostim ${ }^{\circledR}$ are two synthetic bone substitutes, which contain nanocrystalline hydroxyapatite (ncHA). In case of NanoBone ${ }^{\circledR}$, ncHA is embedded in a highly porous matrix of silica gel (Götz et al., 2008), whereas Ostim ${ }^{\circledR}$ is a suspension of ncHA in water, making it a highly viscous, injectable bone substitute (Huber et al., 2008). After implantation into the dorsal skinfold chamber, both materials have been shown to exhibit an excellent biocompatibility comparable to that of cancellous bone, as indicated by a lack of venular leukocyte activation in the host striated muscle tissue (Laschke et al., 2007; Abshagen et al., 2009). In contrast to NanoBone ${ }^{\circledR}$, Ostim ${ }^{\circledR}$ is rapidly degraded, which allows for a guided neovascularisation directed towards areas of degradation (Laschke et al., 2007) (Figs. 6a-d). This may facilitate the early invasion of osteoblasts into the biomaterial and, thus, the formation of new bone after the injection of Ostim ${ }^{\circledR}$ into bone defects.

Medpor $^{\circledR}$ is a porous polyethylene, which is commonly used in plastic and reconstructive surgery for the restoration of contour in the craniofacial skeleton (Xu et al., 2009; Berghaus et al., 2010). For such facial surgical procedures, patients often undergo perioperative steroid therapy to reduce postoperative oedema formation and to shorten recovery time (Kara and Gökalan, 1999; Kargi et al., 2003). However, it was found that Medpor ${ }^{\circledR}$ implanted into the dorsal skinfold chamber of prednisolone-treated balb/c mice exhibits a significantly reduced vascularisation when compared to vehicle-treated controls (Ehrmantraut et al., 2010). These findings indicate that perioperative steroid therapy may be avoided in case of Medpor ${ }^{\circledR}$ implantation to achieve a rapid incorporation of the material at the implantation site. In addition, Strieth et al. (2010) could show that the biocompatibility of porous polyethylene can be improved by incorporation of the extracellular matrix Matrigel $^{\mathrm{TM}}$ enriched with recombinant vascular endothelial growth factor (VEGF). In fact, this modification efficiently reduced the transient initial inflammatory response to 

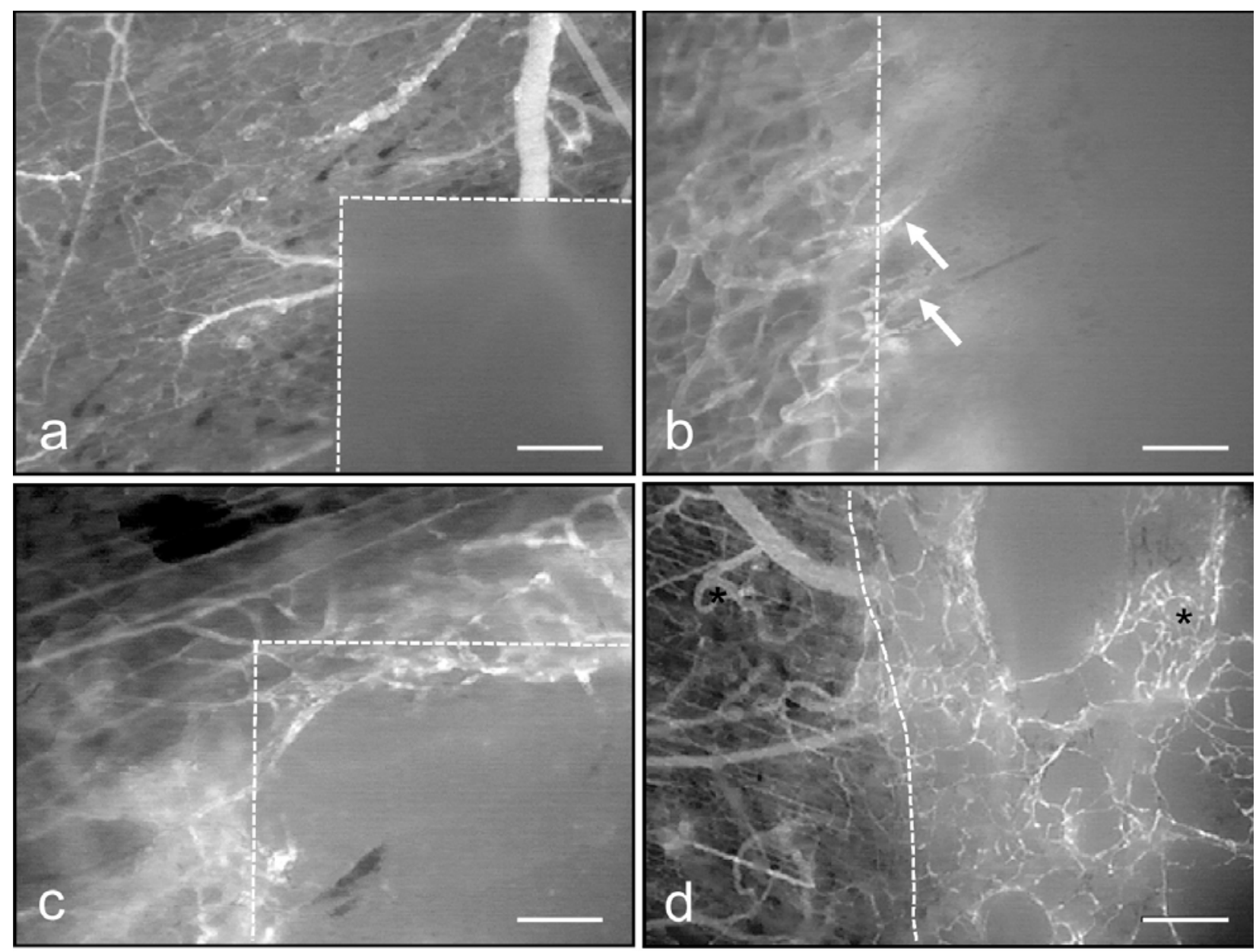

Fig. 6. Intravital fluorescence microscopy (blue light epi-illumination microscopy with intravascular plasma contrast enhancement by $5 \%$ FITC-labelled dextran $(150 \mathrm{kDa})$ i.v. of the synthetic bone substitute Ostim ${ }^{\circledR}$ (border marked by dotted line) at $20 \mathrm{~min}$ (a) as well as at day 3 (b), 6 (c), and 14 (d) after implantation into the dorsal skinfold chamber of a Syrian golden hamster. At day 3, first signs of angiogenesis can be observed in the border zone of the implant, characterised by capillary sprouts (b, arrows). During the following days, these sprouts interconnect with each other to form new microvascular networks around the implant (c). At day 14, newly formed microvessels can also be detected in central surface areas of the implant (d, asterisk). Scale bars: (a, d) $=260 \mu \mathrm{m} ; \mathbf{( b ,} \mathbf{c})=100 \mu \mathrm{m}$.

the implants with a significantly decreased leukocyteendothelial cell interaction in venules of the chamber preparation.

Taken together, these studies demonstrate that the dorsal skinfold chamber allows for the comparative in vivo study of the angiogenic and inflammatory reaction to various bone substitutes under standardised conditions by means of intravital fluorescence microscopy, although this model cannot directly predict bone ingrowth into the implants. Accordingly, a comprehensive characterisation of bone substitutes should be performed by combining this model with other sophisticated in vivo approaches, which enable the study of osteoconductivity and osseointegration, such as the bone chamber (Winet and Albrektsson, 1988; Albrektsson et al., 1989) or non-union models (Garcia et al., 2008).

\section{Scaffolds for tissue engineering}

In tissue engineering, scaffolds serve as three-dimensional matrices for cells to attach, proliferate and finally form a functional tissue substitute (Gloria et al., 2010; Carletti et al., 2011). During the last few years, various scaffold types have been evaluated in terms of biocompatibility and vascularisation in dorsal skinfold chambers of mice. These scaffolds consisted of collagen (Ichioka et al., 2005), collagen-elastin (Ring et al., 2010a), collagen-chitosanhydroxyapatite hydrogel (Rücker et al., 2006), acellular dentin (Rücker et al., 2008), hydroxyapatite (Rücker et al., 2008), $\beta$-tricalcium-phosphate (Lindhorst et al., 2010), poly(ether ester) (Druecke et al., 2004), poly(L-lactideco-glycolide) (PLGA) (Rücker et al., 2006), polyethylene glycol terephthalate/polybutylene terephthalate (PEGT/ PBT) (Ring et al., 2006a,b), lactocapromer terpolymer (Ring et al., 2010b, 2011b), polyurethane (Laschke et al., 2009c, 2010a) and supramolecular nanofibres (Ghanaati et al., 2009). Notably, it was found that the initial vascularisation of the scaffolds is crucially dependent on their biocompatibility. For instance, polyurethane scaffolds, which do not induce a leukocytic inflammatory host tissue response, are only poorly vascularised throughout the first 14 days after implantation (Laschke et al., 2009c, 2010a). In contrast, PLGA scaffolds, which induce a 
slight inflammation, show a strong angiogenic reaction (Rücker et al., 2006). On the other hand, collagen-chitosanhydroxyapatite hydrogel scaffolds, promoting a massive inflammation of the chamber tissue with an increased number of apoptotic cells, demonstrate a complete lack of angiogenesis at the implantation site (Rücker et al., 2006). Finally, hydroxyapatite and dentin scaffolds, which exhibit a biocompatibility comparable to that of isogeneic bone, promote vascularisation to a similar extent as observed in syngeneically implanted bone tissues (Rücker et al., 2008).

The vascularisation of scaffolds is an essential determinant for the success of clinical tissue engineering applications. In fact, long-term survival of threedimensionally constructed tissues, which cannot survive by diffusion alone, crucially depends on a rapid ingrowth of new blood vessels, which provide nutrients and oxygen not only to the cells of the margin but also of the centre of the tissue substitutes (Laschke et al., 2006). By means of the dorsal skinfold chamber model, several approaches have been tested, which may contribute to an improved scaffold vascularisation. These include the modification of pore sizes. In fact, scaffolds with large pores of $250-300 \mu \mathrm{m}$ in diameter significantly improve the ingrowth of new microvessels when compared to scaffolds with pore sizes $<75 \mu \mathrm{m}$ (Druecke et al., 2004, Ring et al., 2006a,b). Moreover, the surface of scaffolds can be activated by biomimetic coating with gas plasma, calcium-phosphate and collagen, resulting in an increased microvessel density of the materials after implantation (Ring et al., 2007, 2010a,c). In addition, scaffolds are loaded with antimicrobial peptides, such as cathelicicin LL37 (Steinstraesser et al., 2006), angiogenic growth factors, such as VEGF (Lindhorst et al., 2010), or growth factor-containing extracellular matrices, such as Matrigel ${ }^{\mathrm{TM}}$ (Laschke et al., 2008a), to stimulate the angiogenic host tissue reaction. Finally, vascularisation of scaffolds can be accelerated by vitalisation with osteoblast-like cells (Schumann et al., 2009; Tavassol et al., 2010) or bone marrow cells (Ichioka et al., 2005; Schumann et al., 2009).

However, all of these approaches face the common problem that angiogenesis is a complex time-consuming process. Previous studies have shown that the physiological growth of blood vessels is not faster than $\sim 5 \mu \mathrm{m} / \mathrm{h}$ (Zarem, 1969; Orr et al., 2003). Accordingly, the ingrowth of microvessels into implanted scaffolds can only be accelerated to a limited extent. This problem may be overcome by the generation of preformed microvascular networks within scaffolds prior to their implantation. In this case, the preformed networks simply have to anastomose to the existing blood vessels of the host tissue after scaffold implantation, representing the process of inosculation (Laschke et al., 2009d) (Figs. 7a-e). Of interest, recent studies indicate that preformed microvessels actively contribute to the process of scaffold vascularisation. After implantation of in situ prevascularised PLGA scaffolds from green fluorescent protein (GFP)-transgenic mice into dorsal skinfold chambers of wild-type recipient animals, intravital fluorescence microscopy demonstrates that GFP-positive vessels grow out from the scaffolds into the surrounding host tissue, where external inosculation occurs (Laschke et al., 2008b). Furthermore, the GFP-positive

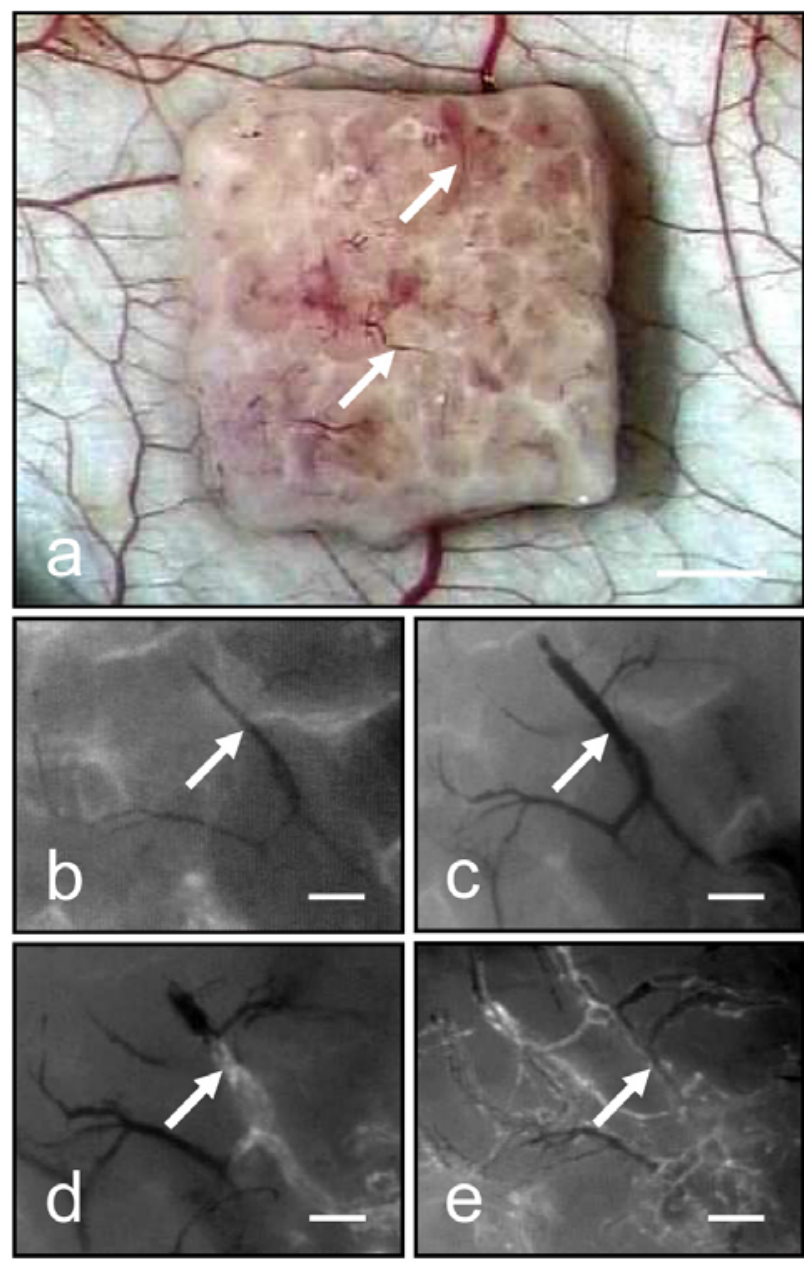

Fig. 7. (a) Porous polyurethane scaffold, which was prevascularised for 20 days in the flank of a donor mouse and subsequently transferred into the dorsal skinfold chamber of a recipient animal. The prevascularised scaffold exhibits already a complete microvascular network of newly formed blood vessels (arrows). (be) Intravital fluorescence microscopy of a preformed blood vessel (arrow) within a tissue portion of the prevascularised scaffold directly after implantation into the dorsal skinfold chamber (b) as well as at day 3 (c), 6 (d) and 14 (e) (blue light with intravascular plasma contrast enhancement by $5 \%$ FITC-labelled dextran $(150 \mathrm{kDa})$ i.v.). Note that until day 3 the preformed microvessel appears dark, indicating lack of FITCdextran-labelled blood perfusion (b, c). At day 6 and 14 the microvessel is reperfused, as indicated by FITCdextran staining (d, e). Scale bars: (a) $=900 \mu \mathrm{m}$; (b-e) $=100 \mu \mathrm{m}$.

preformed vessels contribute to sprouting angiogenesis in the centre of the scaffolds, further increasing the microvessel density of the implants (Laschke et al., 2008b). However, even this approach does not result in adequate blood perfusion of the scaffolds during the very first days after implantation. This is most probably due to the fact that inosculation can only take place, when the preformed blood vessels within a scaffold and the preformed blood vessels of the host tissue have grown towards each other to finally form interconnections. 
Therefore, novel strategies are needed, which further accelerate the process of inosculation. First studies provide evidence that this may be achieved by in vitro short-term cultivation of in situ prevascularised scaffolds. This short-term cultivation results in the destabilisation of their preformed microvascular networks (Laschke et al., 2011), which represents an essential step in the process of angiogenesis. Moreover, the outgrowth of vessel sprouts from prevascularised scaffolds may be promoted by embedding them in an extracellular pro-angiogenic matrix, resulting in an improved external inosculation in the surrounding host tissue after implantation (Laschke et al., 2010b).

\section{Drug delivery systems}

During the past decade, there has been a tremendous increase in the number of drug delivery systems being developed for the local or systemic treatment of pathologic conditions. Many of these systems are based on controlled-release biodegradable polymers, such as PLGA, which permit the sustained and targeted delivery of therapeutic agents. Nickerson et al. (2009) have recently analysed how the degradation of PLGA affects the local microcirculation in dorsal skinfold chambers of mice. They found that the influence of PLGA degradation is limited to luminal arteriolar expansion without apparent effects on the total length of smooth muscle-coated microvessels, indicating that the polymer itself does not induce a relevant arteriogenic remodelling after implantation. In contrast, incorporation of phthalimide neovascular factor (PNF1) into PLGA films resulted in a strong angiogenic host tissue response, which is characterised by the formation of new microvascular networks in direct vicinity of the implants (Wieghaus et al., 2008). Moreover, PNF1 treatment significantly increased the diameters of local arterioles and venules. Similar effects can be observed by incorporation of sphingosine-1-phosphate (S1P) or S1P receptor-selective agonists into the PLGA (Sefcik et al., 2008, 2011).

Ibuprofen is a non-selective cyclooxygenase (COX) inhibitor, which is increasingly used as a pain-reducing component in modern wound dressings. However, because inhibition of COX may also suppress angiogenesis during wound healing, Ring et al. (2008) recently studied the vascularisation of ibuprofen-containing polyurethane foams implanted into dorsal skinfold chambers of mice. Surprisingly, they could demonstrate that the ibuprofenreleasing implants even induced a slightly stronger angiogenic host tissue response when compared to ibuprofen-free foams. Thus, local release of small-dose ibuprofen seems not to have a negative effect on the development of new blood vessels at the implantation site. This finding should be taken into account during the development of novel devices for the local application on wounds.

The dorsal skinfold chamber is not only a suitable in vivo model for biomaterial implantation experiments but is also very useful to gain new insights into the transport and tissue-specific uptake of systemically applied drug delivery systems. In particular in the field of oncology, a broad spectrum of nanoparticulate carriers is currently under investigation for the development of novel antineoplastic agents. By means of sophisticated real-time imaging technologies, it is possible to analyse the processes involved in their delivery to different tumour types established in the dorsal skinfold chamber (Monsky et al., 1999; Jiang et al., 2009; Erten et al., 2010; Hak et al., 2010). These include the interaction of the particles with the microvascular endothelium, their extravasation and intracellular uptake into individual tumour cells (Tada et al., 2007). Of interest, these processes have been shown to be particularly dependent on the size of the used particles (Kawai et al., 2009), their charge (Krasnici et al., 2003) and the local tissue temperature (Gaber et al., 1996; Liu et al., 2004), which should be considered for the development of novel drug delivery systems exhibiting improved pharmacokinetics and anti-tumour activity.

\section{Conclusions}

The dorsal skinfold chamber in combination with sophisticated imaging technologies offers the unique opportunity to analyse in vivo the biocompatibility and vascularisation of small biomaterial implants, which should not exceed a size of $3 \times 3 \times 1 \mathrm{~mm}$. Typically, these analyses are repetitively performed over a limited observation period of 2-3 weeks after biomaterial implantation. Thus, this model is not suitable for long-term studies focusing on the chronic foreign body reaction, but rather for the investigation of the early inflammatory and angiogenic host tissue response to implanted biomaterials, which is crucial for their adequate incorporation into the host tissue. Accordingly, this model has been increasingly used during the last two decades to study the in vivo performance of a broad spectrum of medical devices, including prosthetic vascular grafts, metallic implants, surgical meshes, bone substitutes, scaffolds for tissue engineering and drug delivery systems. These studies have shown that chemical composition, material architecture and surface characteristics are important determinants for the angiogenic and inflammatory host tissue response to the implants. Thus, the dorsal skinfold chamber model does not only provide deep insights into the complex interactions of biomaterials with the surrounding host tissue but also represents an important tool for the future development of novel biomaterials aiming at an optimisation of their biofunctionality in clinical practice. For this purpose, sophisticated analyses focusing on completely new aspects of the in vivo behaviour of implanted biomaterials may be performed by means of the dorsal skinfold chamber model, which cannot easily be done in other animal models. For instance, the in vivo visualisation of the lymphatic vascular system within the chamber (Menger et al., 2003; Schacht et al., 2004) may make it possible to study the lymphatic removal of biomaterial wear particles at the implantation site. Moreover, selective heating (Harder et al., 2005) or cooling (Thorlacius et al., 1998; Westermann et al., 1999) of the chamber may offer the unique opportunity to analyse the temperature-dependent biofunctionality of thermosensitive biomaterials (Vermonden et al., 2010; 
Wang et al., 2010) without affecting the general condition of the experimental animal.

\section{Acknowledgements}

We are grateful for the excellent assistance of Janine Becker, Jörg M. Häufel, Christina Körbel, Haider Mussawy, Anja Strohe and Kristina Witt while creating the figures.

\section{References}

Abshagen K, Schrodi I, Gerber T, Vollmar B (2009) In vivo analysis of biocompatibility and vascularization of the synthetic bone grafting substitute NanoBone. J Biomed Mater Res A 91: 557-566.

Albrektsson T, Eriksson AR, Jacobsson M, Kälebo P, Strid KG, Tjellström A (1989) Bone repair in implant models: a review with emphasis on the harvest chamber for bone regeneration studies. Int J Oral Maxillofac Implants 4: 45-54.

Algire GH (1943) An adaption of the transparent chamber technique to the mouse. J Natl Cancer Inst 4: 1-11.

Anderson JM, Rodriguez A, Chang DT (2008) Foreign body reaction to biomaterials. Semin Immunol 20: 86-100.

Arfors KE, Jonsson JA, McKenzie FN (1970) A titanium rabbit ear chamber: assembly, insertion and results. Microvasc Res 2: 516-518.

Baatz H, Steinbauer M, Harris AG, Krombach F (1995) Kinetics of white blood cell staining by intravascular administration of rhodamine 6G. Int J Microcirc Clin Exp 15: 85-91.

Becker M, Menger MD, Lehr HA (1994) Heparinreleased superoxide dismutase inhibits postischemic leukocyte adhesion to venular endothelium. Am J Physiol 267: H925-H930.

Berghaus A, Stelter K, Naumann A, Hempel JM (2010) Ear reconstruction with porous polyethylene implants. Adv Otorhinolaryngol 68: 53-64.

Bodin A, Bäckdahl H, Fink H, Gustafsson L, Risberg B, Gatenholm P (2007) Influence of cultivation conditions on mechanical and morphological properties of bacterial cellulose tubes. Biotechnol Bioeng 97: 425-434.

Bonhomme S, Trotteur G, Van Damme H, Defraigne JO (2010) Thrombolysis of occluded infra-inguinal bypass grafts: is it worthwhile? Acta Chir Belg 110: 445-450.

Borrero E, Doscher W (1988) Chronic perigraft seromas in PTFE grafts. J Cardiovasc Surg (Torino) 29: 46-49.

Brown RM Jr, Willison JH, Richardson CL (1976) Cellulose biosynthesis in Acetobacter xylinum: visualization of the site of synthesis and direct measurement of the in vivo process. Proc Natl Acad Sci U S A 73: 4565-4569.

Burger JW, Luijendijk RW, Hop WC, Halm JA, Verdaasdonk EG, Jeekel J (2004) Long-term follow-up of a randomized controlled trial of suture versus mesh repair of incisional hernia. Ann Surg 240: 578-583.
Busenlechner D, Tangl S, Mair B, Fugger G, Gruber R, Redl H, Watzek G (2008) Simultaneous in vivo comparison of bone substitutes in a guided bone regeneration model. Biomaterials 29: 3195-3200.

Cardon SZ, Oestermeyer CF, Bloch EH (1970) Effect of oxygen on cyclic red blood cell flow in unanesthetized mammalian striated muscle as determined by microscopy. Microvasc Res 2: 67-76.

Carletti E, Motta A, Migliaresi C (2011) Scaffolds for tissue engineering and 3D cell culture. Methods Mol Biol 695: 17-39.

Chiesa R, Astore D, Frigerio S, Garriboli L, Piccolo G, Castellano R, Scalamogna M, Odero A, Pirrelli S, Biasi G, Mingazzini P, Biglioli P, Polvani G, Guarino A, Agrifoglio G, Tori A, Spina G (2002) Vascular prosthetic graft infection: epidemiology, bacteriology, pathogenesis and treatment. Acta Chir Belg 102: 238-247.

Contaldo C, Meier C, Elsherbiny A, Harder Y, Trentz O, Menger MD, Wanner GA (2007) Human recombinant erythropoietin protects the striated muscle microcirculation of the dorsal skinfold from postischemic injury in mice. Am J Physiol Heart Circ Physiol 293: H274-283.

Druecke D, Langer S, Lamme E, Pieper J, Ugarkovic M, Steinau HU, Homann HH (2004) Neovascularization of poly(ether ester) block-copolymer scaffolds in vivo: longterm investigations using intravital fluorescent microscopy. J Biomed Mater Res A 68: 10-18.

Ehrmantraut S, Laschke MW, Merkel D, Scheuer C, Willnecker V, Meyer-Lindenberg A, Menger MD, Naumann A (2010) Perioperative steroid administration inhibits angiogenic host tissue response to porous polyethylene (Medpor) implants. Eur Cell Mater 19: 107116.

Endrich B, Asaishi K, Götz A, Messmer K (1980) Technical report - a new chamber technique for microvascular studies in unanesthetized hamsters. Res Exp Med (Berl) 177: 125-134.

Erten A, Wrasidlo W, Scadeng M, Esener S, Hoffman RM, Bouvet M, Makale M (2010) Magnetic resonance and fluorescence imaging of doxorubicin-loaded nanoparticles using a novel in vivo model. Nanomedicine 6: 797-807.

Esguerra M, Fink H, Laschke MW, Jeppsson A, Delbro D, Gatenholm P, Menger MD, Risberg B (2010) Intravital fluorescent microscopic evaluation of bacterial cellulose as scaffold for vascular grafts. J Biomed Mater Res A 93: 140-149.

Gaber MH, Wu NZ, Hong K, Huang SK, Dewhirst MW, Papahadjopoulos D (1996) Thermosensitive liposomes: extravasation and release of contents in tumor microvascular networks. Int J Radiat Oncol Biol Phys 36: 1177-1187.

Garcia P, Holstein JH, Maier S, Schaumlöffel H, AlMarrawi F, Hannig M, Pohlemann T, Menger MD (2008) Development of a reliable non-union model in mice. J Surg Res 147: 84-91.

Gaustad JV, Brurberg KG, Simonsen TG, Mollatt CS, Rofstad EK (2008) Tumor vascularity assessed by magnetic resonance imaging and intravital microscopy imaging. Neoplasia 10: 354-362. 
Ghanaati S, Webber MJ, Unger RE, Orth C, Hulvat JF, Kiehna SE, Barbeck M, Rasic A, Stupp SI, Kirkpatrick CJ (2009) Dynamic in vivo biocompatibility of angiogenic peptide amphiphile nanofibers. Biomaterials 30: 62026212.

Giannoudis PV, Dinopoulos H, Tsiridis E (2005) Bone substitutes: an update. Injury 36 Suppl 3: S20-27.

Glaeser JD, Geissler S, Ode A, Schipp CJ, Matziolis G, Taylor WR, Knaus P, Perka C, Duda GN, Kasper G (2010) Modulation of matrix metalloprotease-2 levels by mechanical loading of three-dimensional mesenchymal stem cell constructs: impact on in vitro tube formation. Tissue Eng Part A 16: 3139-3148.

Gloria A, De Santis R, Ambrosio L (2010) Polymerbased composite scaffolds for tissue engineering. J Appl Biomater Biomech 8: 57-67.

Götz W, Gerber T, Michel B, Lossdörfer S, Henkel KO, Heinemann F (2008) Immunohistochemical characterization of nanocrystalline hydroxyapatite silica gel (NanoBone(r)) osteogenesis: a study on biopsies from human jaws. Clin Oral Implants Res 19: 1016-1026.

Gray JJ (2004) The interaction of proteins with solid surfaces. Curr Opin Struct Biol 14: 110-115.

Hak S, Reitan NK, Haraldseth O, de Lange Davies C (2010) Intravital microscopy in window chambers: a unique tool to study tumor angiogenesis and delivery of nanoparticles. Angiogenesis 13: 113-130.

Harder Y, Amon M, Schramm R, Georgi M, Banic A, Erni D, Menger MD (2005) Heat shock preconditioning reduces ischemic tissue necrosis by heat shock protein (HSP)-32-mediated improvement of the microcirculation rather than induction of ischemic tolerance. Ann Surg 242: 869-878, discussion 878-879.

Harris AG, Steinbauer M, Leiderer R, Messmer K (1997) Role of leukocyte plugging and edema in skeletal muscle ischemia-reperfusion injury. Am J Physiol 273: H989-996.

Hauser J, Ring A, Schaffran A, Henrich L, Esenwein SA, Steinau HU, Stricker I, Langer S (2009) In vivo analysis of tissue response to plasma-treated collagen-Icoated titanium alloys. Eur Surg Res 43: 262-268.

Herscu G, Wilson SE (2009) Prosthetic infection: lessons from treatment of the infected vascular graft. Surg Clin North Am 89: 391-401.

Huber FX, Berger I, McArthur N, Huber C, Kock HP, Hillmeier J, Meeder PJ (2008) Evaluation of a novel nanocrystalline hydroxyapatite paste and a solid hydroxyapatite ceramic for the treatment of critical size bone defects (CSD) in rabbits. J Mater Sci Mater Med 19: 33-38.

Ichioka S, Kouraba S, Sekiya N, Ohura N, Nakatsuka $\mathrm{T}$ (2005) Bone marrow-impregnated collagen matrix for wound healing: experimental evaluation in a microcirculatory model of angiogenesis, and clinical experience. Br J Plast Surg 58: 1124-1130.

Isaka N, Padera TP, Hagendoorn J, Fukumura D, Jain RK (2004) Peritumor lymphatics induced by vascular endothelial growth factor-C exhibit abnormal function. Cancer Res 64: 4400-4404.
Ishii T, Ishii M (2011) Intravital two-photon imaging: a versatile tool for dissecting the immune system. Ann Rheum Dis 70 Suppl 1: i113-115.

Jacobs JJ, Gilbert JL, Urban RM (1998) Corrosion of metal orthopaedic implants. J Bone Joint Surg Am 80: 268-282.

Jezupovs A, Mihelsons M (2006) The analysis of infection after polypropylene mesh repair of abdominal wall hernia. World J Surg 30: 2270-2278.

Jiang G, Jiang Y, Shen Y, Nam KH, Lee D, Gao Z (2009) DNA loaded carrier preferential extravasation from tumor blood vessel. Int J Pharm 369: 155-161.

Kahn J, Müller H, Iberer F, Kniepeiss D, Duller D, Rehak P, Tscheliessnigg K (2007) Incisional hernia following liver transplantation: incidence and predisposing factors. Clin Transplant 21: 423-426.

Kara CO, Gökalan I (1999) Effects of single-dose steroid usage on edema, ecchymosis, and intraoperative bleeding in rhinoplasty. Plast Reconstr Surg 104: 22132218.

Kargi E, Hoşnuter M, Babucçu O, Altunkaya H, Altinyazar C (2003) Effect of steroids on edema, ecchymosis, and intraoperative bleeding in rhinoplasty. Ann Plast Surg 51: 570-574.

Kasper G, Dankert N, Tuischer J, Hoeft M, Gaber T, Glaeser JD, Zander D, Tschirschmann M, Thompson M, Matziolis G, Duda GN (2007) Mesenchymal stem cells regulate angiogenesis according to their mechanical environment. Stem Cells 25: 903-910.

Kawai M, Higuchi H, Takeda M, Kobayashi Y, Ohuchi N (2009) Dynamics of different-sized solid-state nanocrystals as tracers for a drug-delivery system in the interstitium of a human tumor xenograft. Breast Cancer Res 11: R43.

Kelley SF, Felix AM, Ehrlich HP (1990) The antagonism of glucocorticoid inhibition of wound healing in rats by growth hormone-releasing factor. Proc Soc Exp Biol Med 194: 320-326.

Kerdudou S, Laschke MW, Sinha B, Preissner KT, Menger MD, Herrmann M (2006) Fibronectin binding proteins contribute to the adherence of Staphylococcus aureus to intact endothelium in vivo. Thromb Haemost 96: 183-189.

Kerger H, Saltzman DJ, Menger MD, Messmer K, Intaglietta M (1996) Systemic and subcutaneous microvascular Po2 dissociation during 4-h hemorrhagic shock in conscious hamsters. Am J Physiol 270: H827-836.

Keselowsky BG, Bridges AW, Burns KL, Tate CC, Babensee JE, LaPlaca MC, García AJ (2007) Role of plasma fibronectin in the foreign body response to biomaterials. Biomaterials 28: 3626-3631.

Kim K, Yeatts A, Dean D, Fisher JP (2010) Stereolithographic bone scaffold design parameters: osteogenic differentiation and signal expression. Tissue Eng Part B Rev 16: 523-539.

Kou PM, Babensee JE (2011) Macrophage and dendritic cell phenotypic diversity in the context of biomaterials. J Biomed Mater Res A 96: 239-260. 
Kraft CN, Hansis M, Arens S, Menger MD, Vollmar B (2000) Striated muscle microvascular response to silver implants: A comparative in vivo study with titanium and stainless steel. J Biomed Mater Res 49: 192-199.

Kraft CN, Burian B, Perlick L, Wimmer MA, Wallny T, Schmitt O, Diedrich O (2001a) Impact of a nickel-reduced stainless steel implant on striated muscle microcirculation: a comparative in vivo study. J Biomed Mater Res 57: 404412.

Kraft CN, Burian B, Diedrich O, Wimmer MA (2001b) Implications of orthopedic fretting corrosion particles on skeletal muscle microcirculation. J Mater Sci Mater Med 12: $1057-1062$.

Kraft CN, Weber W, Burian B, Zander D, Wallny T, Schmitt O, Diedrich O (2002) Striated muscle microvascular response to implants with sol-gel calcium phosphate coating. A comparative in vivo study. Z Orthop Ihre Grenzgeb 140: 672-680.

Kraft CN, Diedrich O, Burian B, Schmitt O, Wimmer MA (2003) Microvascular response of striated muscle to metal debris. A comparative in vivo study with titanium and stainless steel. J Bone Joint Surg Br 85: 133-141.

Kraft CN, Burian B, Diedrich O, Gessmann J, Wimmer MA, Pennekamp PH (2005) Microvascular response of striated muscle to common arthroplasty-alloys: A comparative in vivo study with CoCrMo, Ti-6Al-4V, and Ti-6Al-7Nb. J Biomed Mater Res A 75: 31-40.

Kraiss LW, Johansen K (1995) Pharmacologic intervention to prevent graft failure. Surg Clin North Am 75: 761-772.

Krasnici S, Werner A, Eichhorn ME, Schmitt-Sody M, Pahernik SA, Sauer B, Schulze B, Teifel M, Michaelis U, Naujoks K, Dellian M (2003) Effect of the surface charge of liposomes on their uptake by angiogenic tumor vessels. Int J Cancer 105: 561-567.

Laschke MW, Häufel JM, Thorlacius H, Menger MD (2005a) New experimental approach to study host tissue response to surgical mesh materials in vivo. J Biomed Mater Res A 74: 696-704.

Laschke MW, Kerdudou S, Herrmann M, Menger MD (2005b) Intravital fluorescence microscopy: a novel tool for the study of the interaction of Staphylococcus aureus with the microvascular endothelium in vivo. J Infect Dis 191: 435-443.

Laschke MW, Harder Y, Amon M, Martin I, Farhadi J, Ring A, Torio-Padron N, Schramm R, Rücker M, Junker D, Häufel JM, Carvalho C, Heberer M, Germann G, Vollmar $\mathrm{B}$, Menger MD (2006) Angiogenesis in tissue engineering: breathing life into constructed tissue substitutes. Tissue Eng 12: 2093-2104.

Laschke MW, Witt K, Pohlemann T, Menger MD (2007) Injectable nanocrystalline hydroxyapatite paste for bone substitution: in vivo analysis of biocompatibility and vascularization. J Biomed Mater Res B Appl Biomater 82: 494-505.

Laschke MW, Rücker M, Jensen G, Carvalho C, Mülhaupt R, Gellrich NC, Menger MD (2008a) Incorporation of growth factor containing Matrigel promotes vascularization of porous PLGA scaffolds. J Biomed Mater Res A 85: 397-407.
Laschke MW, Rücker M, Jensen G, Carvalho C, Mülhaupt R, Gellrich NC, Menger MD (2008b) Improvement of vascularization of PLGA scaffolds by inosculation of in situ preformed functional blood vessels with the host microvasculature. Ann Surg 248: 939-948.

Laschke MW, Häufel JM, Scheuer C, Menger MD (2009a) Angiogenic and inflammatory host response to surgical meshes of different mesh architecture and polymer composition. J Biomed Mater Res B Appl Biomater 91: 497-507.

Laschke MW, Häufel JM, Roller J, Schorr H, Menger MD (2009b) Rapamycin, but not cyclosporine A, inhibits vascularization and incorporation of implanted surgical meshes. Transpl Int 22: 654-662.

Laschke MW, Strohe A, Scheuer C, Eglin D, Verrier S, Alini M, Pohlemann T, Menger MD (2009c) In vivo biocompatibility and vascularization of biodegradable porous polyurethane scaffolds for tissue engineering. Acta Biomater 5: 1991-2001.

Laschke MW, Vollmar B, Menger MD (2009d) Inosculation: connecting the life-sustaining pipelines. Tissue Eng Part B Rev 15: 455-465.

Laschke MW, Strohe A, Menger MD, Alini M, Eglin D (2010a) In vitro and in vivo evaluation of a novel nanosize hydroxyapatite particles/poly(ester-urethane) composite scaffold for bone tissue engineering. Acta Biomater 6: 2020-2027.

Laschke MW, Mussawy H, Schuler S, Eglin D, Alini M, Menger MD (2010b) Promoting external inosculation of prevascularised tissue constructs by pre-cultivation in an angiogenic extracellular matrix. Eur Cell Mater 20: 356-366.

Laschke MW, Mussawy H, Schuler S, Kazakov A, Rücker M, Eglin D, Alini M, Menger MD (2011) Shortterm cultivation of in situ prevascularized tissue constructs accelerates inosculation of their preformed microvascular networks after implantation into the host tissue. Tissue Eng Part A 17: 841-853.

Lehr HA, Leunig M, Menger MD, Nolte D, Messmer K (1993) Dorsal skinfold chamber technique for intravital microscopy in nude mice. Am J Pathol 143: 1055-1062.

Leunig M, Yuan F, Menger MD, Boucher Y, Goetz AE, Messmer K, Jain RK (1992) Angiogenesis, microvascular architecture, microhemodynamics, and interstitial fluid pressure during early growth of human adenocarcinoma LS174T in SCID mice. Cancer Res 52: 6553-6560.

Lindhorst D, Tavassol F, von See C, Schumann P, Laschke MW, Harder Y, Bormann KH, Essig H, Kokemüller H, Kampmann A, Voss A, Mülhaupt R, Menger MD, Gellrich NC, Rücker M (2010) Effects of VEGF loading on scaffold-confined vascularization. J Biomed Mater Res A 95: 783-792.

Liu P, Zhang A, Zhou M, Xu Y, Xu LX (2004) Real time 3D detection of nanoparticle liposomes extravasation using laser confocal microscopy. Conf Proc IEEE Eng Med Biol Soc 4: 2662-2665.

Luijendijk RW, Hop WC, van den Tol MP, de Lange DC, Braaksma MM, IJzermans JN, Boelhouwer RU, de Vries BC, Salu MK, Wereldsma JC, Bruijninckx CM, 
Jeekel J (2000) A comparison of suture repair with mesh repair for incisional hernia. N Engl J Med 343: 392-398.

Makale M (2007) Intravital imaging and cell invasion. Methods Enzymol 426: 375-401.

Menger MD, Hammersen F, Walter P, Messmer K (1990a) Neovascularization of prosthetic vascular grafts. Quantitative analysis of angiogenesis and microhemodynamics by means of intravital microscopy. Thorac Cardiovasc Surg 38: 139-145.

Menger MD, Walter P, Hammersen F, Messmer K (1990b) Quantitative analysis of neovascularization of different PTFE-implants. Eur J Cardiothorac Surg 4: 191196.

Menger MD, Pelikan S, Steiner D, Messmer K (1992a) Microvascular ischemia-reperfusion injury in striated muscle: significance of "reflow paradox". Am J Physiol 263: H1901-1906.

Menger MD, Barker JH, Messmer K (1992b) Capillary blood perfusion during postischemic reperfusion in striated muscle. Plast Reconstr Surg 89: 1104-1114.

Menger MD, Hammersen F, Messmer K (1992c) In vivo assessment of neovascularization and incorporation of prosthetic vascular biografts. Thorac Cardiovasc Surg 40: 19-25.

Menger MD, Laschke MW, Vollmar B (2002) Viewing the microcirculation through the window: some twenty years experience with the hamster dorsal skinfold chamber. Eur Surg Res 34: 83-91.

Menger MD, Laschke MW, Amon M, Schramm R, Thorlacius H, Rücker M, Vollmar B (2003) Experimental models to study microcirculatory dysfunction in muscle ischemia-reperfusion and osteomyocutaneous flap transfer. Langenbecks Arch Surg 388: 281-290.

Monsky WL, Fukumura D, Gohongi T, Ancukiewcz M, Weich HA, Torchilin VP, Yuan F, Jain RK (1999) Augmentation of transvascular transport of macromolecules and nanoparticles in tumors using vascular endothelial growth factor. Cancer Res 59: 4129-4135.

Monteiro DR, Gorup LF, Takamiya AS, Ruvollo-Filho AC, de Camargo ER, Barbosa DB (2009) The growing importance of materials that prevent microbial adhesion: antimicrobial effect of medical devices containing silver. Int J Antimicrob Agents 34: 103-110.

Morais JM, Papadimitrakopoulos F, Burgess DJ (2010) Biomaterials/tissue interactions: possible solutions to overcome foreign body response. AAPS J 12: 188-196.

Naik MN, Murthy RK, Honavar SG (2007) Comparison of vascularization of Medpor and Medpor-Plus orbital implants: a prospective, randomized study. Ophthal Plast Reconstr Surg 23: 463-467.

Nickerson MM, Song J, Shuptrine CW, Wieghaus KA, Botchwey EA, Price RJ (2009) Influence of poly(D,Llactic-co-glycolic acid) microsphere degradation on arteriolar remodeling in the mouse dorsal skinfold window chamber. J Biomed Mater Res A 91: 317-323.

Orr AW, Elzie CA, Kucik DF, Murphy-Ullrich JE (2003) Thrombospondin signaling through the calreticulin/ LDL receptor-related protein co-complex stimulates random and directed cell migration. J Cell Sci 116: $2917-$ 2927.
Papenfuss HD, Gross JF, Intaglietta M, Treese FA (1979) A transparent access chamber for the rat dorsal skin fold. Microvasc Res 18: 311-318.

Pennekamp PH, Gessmann J, Diedrich O, Burian B, Wimmer MA, Frauchiger VM, Kraft CN (2006) Shortterm microvascular response of striated muscle to $\mathrm{cp}-\mathrm{Ti}$, Ti-6Al-4V, and Ti-6Al-7Nb. J Orthop Res 24: 531-540.

Pennekamp PH, Wimmer MA, Eschbach L, Burian B, Koch P, Kraft CN (2007) Microvasculatory reaction of skeletal muscle to Ti-15Mo in comparison to wellestablished titanium alloys. J Mater Sci Mater Med 18: 2053-2060.

Rahlf G, Urban P, Bohle RM (1986) Morphology of healing in vascular prostheses. Thorac Cardiovasc Surg 34: 43-48.

Ring A, Goertz O, Steinstraesser L, Kuhnen C, Schmitz I, Muhr G, Steinau HU, Langer S (2006a) Analysis of biodegradation of copolymer dermis substitutes in the dorsal skinfold chamber of balb/c mice. Eur J Med Res 11: 471-478.

Ring A, Langer S, Homann $\mathrm{HH}$, Kuhnen C, Schmitz I, Steinau HU, Drücke D (2006b) Analysis of neovascularization of PEGT/PBT-copolymer dermis substitutes in balb/c-mice. Burns 32: 35-41.

Ring A, Steinstraesser L, Muhr G, Steinau HU, Hauser J, Langer S (2007) Improved neovascularization of PEGT/PBT copolymer matrices in response to surface modification by biomimetic coating. Eur Surg Res 39: $75-81$

Ring A, Goertz O, Muhr G, Steinau HU, Langer S (2008) In vivo microvascular response of murine cutaneous muscle to ibuprofen-releasing polyurethane foam. Int Wound J 5: 464-469.

Ring A, Langer S, Schaffran A, Stricker I, Awakowicz P, Steinau HU, Hauser J (2010a) Enhanced neovascularization of dermis substitutes via low-pressure plasma-mediated surface activation. Burns 36: 1222-1227.

Ring A, Goertz O, Al-Benna S, Ottomann C, Langer S, Steinstraesser L, Schmitz I, Tilkorn D (2010b) Accelerated angiogenic induction and vascular integration in a novel synthetic scaffolding matrix for tissue replacement. Int $\mathrm{J}$ Artif Organs 33: 877-884.

Ring A, Langer S, Tilkorn D, Goertz O, Henrich L, Stricker I, Steinau HU, Steinstraesser L, Hauser J (2010c) Induction of angiogenesis and neovascularization in adjacent tissue of plasma-collagen-coated silicone implants. Eplasty 10 pii: e61.

Ring A, Tilkorn DJ, Goertz O, Langer S, Schaffran A, Awakowicz P, Hauser J (2011a) Surface modification by glow discharge gasplasma treatment improves vascularization of allogenic bone implants. J Orthop Res 29: $1237-1244$.

Ring A, Tilkorn D, Ottomann C, Geomelas M, Steinstraesser L, Langer S, Goertz O (2011b) Intravital monitoring of microcirculatory and angiogenic response to lactocapromer terpolymer matrix in a wound model. Int Wound J 8: 112-117.

Robinson TN, Clarke JH, Schoen J, Walsh MD (2005) Major mesh-related complications following hernia repair: 
events reported to the Food and Drug Administration. Surg Endosc 19: 1556-1560.

Roetman B, Ring A, Langer S, Schildhauer TA, Muhr G, Köller M (2010) Microvascular response to calcium phosphate bone substitutes: an intravital microscopy analysis. Langenbecks Arch Surg 395: 1147-1155.

Roll S, Müller-Nordhorn J, Keil T, Scholz H, Eidt D, Greiner W, Willich SN (2008) Dacron vs. PTFE as bypass materials in peripheral vascular surgery - systematic review and meta-analysis. BMC Surg 8: 22.

Roller J, Laschke MW, Sethi S, Herrmann M, Menger MD (2008) Prolene-Monocryl-composite meshes do not increase microvascular Staphylococcus aureus adherence and do not sensitize for leukocytic inflammation. Langenbecks Arch Surg 393: 349-357.

Rücker M, Laschke MW, Junker D, Carvalho C, Schramm A, Mülhaupt R, Gellrich NC, Menger MD (2006) Angiogenic and inflammatory response to biodegradable scaffolds in dorsal skinfold chambers of mice. Biomaterials 27: 5027-5038.

Rücker M, Laschke MW, Junker D, Carvalho C, Tavassol F, Mülhaupt R, Gellrich NC, Menger MD (2008) Vascularization and biocompatibility of scaffolds consisting of different calcium phosphate compounds. J Biomed Mater Res A 86: 1002-1011.

Rutkow IM (2003) Demographic and socioeconomic aspects of hernia repair in the United States in 2003. Surg Clin North Am 83: 1045-1051.

Ryan G, Pandit A, Apatsidis DP (2006) Fabrication methods of porous metals for use in orthopaedic applications. Biomaterials 27: 2651-2670.

Sandino C, Checa S, Prendergast PJ, Lacroix D (2010) Simulation of angiogenesis and cell differentiation in a $\mathrm{CaP}$ scaffold subjected to compressive strains using a lattice modeling approach. Biomaterials 31: 2446-2452.

Sandison JC (1928) The transparent chamber of the rabbit's ear giving a complete description of improved techniques of construction and introduction and general account of growth and behaviour of living cells and tissues seen with the microscope. Am J Anat 41: 447-472.

Schacht V, Berens von Rautenfeld D, Abels C (2004) The lymphatic system in the dorsal skinfold chamber of the Syrian golden hamster in vivo. Arch Dermatol Res 295: 542-548.

Schäfer SC, Sehrt DN, Kamler M, Jakob H, Lehr HA (2005) Paradoxical attenuation of leukocyte rolling in response to ischemia- reperfusion and extracorporeal blood circulation in inflamed tissue. Am J Physiol Heart Circ Physiol 289: H330-H335.

Schäffer M, Schier R, Napirei M, Michalski S, Traska T, Viebahn R (2007) Sirolimus impairs wound healing. Langenbecks Arch Surg 392: 297-303.

Schumann P, Tavassol F, Lindhorst D, Stuehmer C, Bormann KH, Kampmann A, Mülhaupt R, Laschke MW, Menger MD, Gellrich NC, Rücker M (2009) Consequences of seeded cell type on vascularization of tissue engineering constructs in vivo. Microvasc Res 78: 180-190.

Sclafani AP, Thomas JR, Cox AJ, Cooper MH (1997) Clinical and histologic response of subcutaneous expanded polytetrafluoroethylene (Gore-Tex) and porous high- density polyethylene (Medpor) implants to acute and early infection. Arch Otolaryngol Head Neck Surg 123: 328-336.

Sefcik LS, Petrie Aronin CE, Wieghaus KA, Botchwey EA (2008) Sustained release of sphingosine 1-phosphate for therapeutic arteriogenesis and bone tissue engineering. Biomaterials 29: 2869-2877.

Sefcik LS, Petrie Aronin CE, Awojoodu AO, Shin SJ, Mac Gabhann F, Macdonald TL, Wamhoff BR, Lynch KR, Peirce SM, Botchwey EA (2011) Selective activation of sphingosine 1-phosphate receptors 1 and 3 promotes local microvascular network growth. Tissue Eng Part A 17: 617629.

Seiler JG 3rd, Johnson J (2000) Iliac crest autogenous bone grafting: donor site complications. J South Orthop Assoc 9: 91-97.

Shankaran V, Weber DJ, Reed RL 2nd, Luchette FA (2011) A review of available prosthetics for ventral hernia repair. Ann Surg 253: 16-26.

Steinstraesser L, Ring A, Bals R, Steinau HU, Langer S (2006) The human host defense peptide LL37/hCAP accelerates angiogenesis in PEGT/PBT biopolymers. Ann Plast Surg 56: 93-98.

Strieth S, Nussbaum CF, Eichhorn ME, Fuhrmann M, Teifel M, Michaelis U, Berghaus A, Dellian M (2008) Tumor-selective vessel occlusions by platelets after vascular targeting chemotherapy using paclitaxel encapsulated in cationic liposomes. Int J Cancer 122: 452460.

Strieth S, Weger T, Bartesch C, Bittmann P, Stelter K, Berghaus A (2010) Biocompatibility of porous polyethylene implants tissue-engineered by extracellular matrix and VEGF. J Biomed Mater Res A 93: 1566-1573.

Svirskis D, Travas-Sejdic J, Rodgers A, Garg S (2010) Electrochemically controlled drug delivery based on intrinsically conducting polymers. J Control Release 146: 6-15.

Tada H, Higuchi H, Wanatabe TM, Ohuchi N (2007) In vivo real-time tracking of single quantum dots conjugated with monoclonal anti-HER2 antibody in tumors of mice. Cancer Res 67: 1138-1144.

Tavassol F, Schumann P, Lindhorst D, Sinikovic B, Voss A, von See C, Kampmann A, Bormann KH, Carvalho C, Mülhaupt R, Harder Y, Laschke MW, Menger MD, Gellrich NC, Rücker M (2010) Accelerated angiogenic host tissue response to poly(L-lactide-co-glycolide) scaffolds by vitalization with osteoblast-like cells. Tissue Eng Part A 16: 2265-2279.

Thevenot P, Hu W, Tang L (2008) Surface chemistry influences implant biocompatibility. Curr Top Med Chem 8: 270-280.

Thorlacius H, Vollmar B, Westermann S, Törkvist L, Menger MD (1998) Effects of local cooling on microvascular hemodynamics and leukocyte adhesion in the striated muscle of hamsters. J Trauma 45: 715-719.

Ushiyama A, Yamada S, Ohkubo C (2004) Microcirculatory parameters measured in subcutaneous tissue of the mouse using a novel dorsal skinfold chamber. Microvasc Res 68: 147-152.

Velard F, Laurent-Maquin D, Braux J, Guillaume C, Bouthors S, Jallot E, Nedelec JM, Belaaouaj A, Laquerriere 
P (2010) The effect of zinc on hydroxyapatite-mediated activation of human polymorphonuclear neutrophils and bone implant-associated acute inflammation. Biomaterials 31: 2001-2009.

Vermonden T, Jena SS, Barriet D, Censi R, van der Gucht J, Hennink WE, Siegel RA (2010) Macromolecular diffusion in self-assembling biodegradable thermosensitive hydrogels. Macromolecules 43: 782-789.

Vollmar B, Laschke MW, Rohan R, Koenig J, Menger MD (2001) In vivo imaging of physiological angiogenesis from immature to preovulatory ovarian follicles. Am J Pathol 159: 1661-1670.

Wang F, Li Z, Khan M, Tamama K, Kuppusamy P, Wagner WR, Sen CK, Guan J (2010) Injectable, rapid gelling and highly flexible hydrogel composites as growth factor and cell carriers. Acta Biomater 6: 1978-1991.

Westermann S, Vollmar B, Thorlacius H, Menger MD (1999) Surface cooling inhibits tumor necrosis factoralpha-induced microvascular perfusion failure, leukocyte adhesion, and apoptosis in the striated muscle. Surgery 126: 881-889.

Wieghaus KA, Nickerson MM, Petrie Aronin CE, Sefcik LS, Price RJ, Paige MA, Brown ML, Botchwey EA (2008) Expansion of microvascular networks in vivo by phthalimide neovascular factor 1 (PNF1). Biomaterials 29: 4698-4708.

Winet H, Albrektsson T. Wound healing in the bone chamber 1. Neoosteogenesis during transition from the repair to the regenerative phase in the rabbit tibial cortex (1988) J Orthop Res 6: 531-539.

Xia Z, Triffitt JT (2006) A review on macrophage responses to biomaterials. Biomed Mater 1: R1-9.

Xu JJ, Teng L, Jin XL, Ji Y, Lu JJ, Zhang B (2009) Porous polyethylene implants in orbital blow-out fractures and enophthalmos reconstruction. J Craniofac Surg 20: 918-920.

Zarem HA (1969) The microcirculatory events within full-thickness skin allografts (homografts) in mice. Surgery 66: 392-397.

Zetrenne E, McIntosh BC, McRae MH, Gusberg R, Evans GR, Narayan D (2007) Prosthetic vascular graft infection: a multi-center review of surgical management. Yale J Biol Med 80: 113-121.

\section{Discussion with Reviewers}

Reviewer I: Please discuss the advantages and the limitations of this experimental model in more detail, regarding (1) advantages compared to subcutaneous implantation, (2) methods used for the following of the newly formed tissue, (3) the absence of mechanical strain. Authors: (1) The classical experimental approach to study biocompatibility, vascularisation and tissue incorporation of biomaterials is their implantation into a subcutaneous pocket. In this case, data are normally based on histological and immunohistochemical analyses of isolated biomaterial samples at a single observation time point. In contrast, the dorsal skinfold chamber is a chronic in vivo model, which allows for the non-invasive and repetitive analysis of the angiogenic and inflammatory host tissue response to implanted biomaterials in individual animals over time. This maximises the amount of data obtained from each animal and, by this, limits the statistical variability and reduces the number of animals required for a study. Moreover, in contrast to histological and immunohistochemical analyses, measurements in the dorsal skinfold chamber are performed in living animals, which enables the detailed assessment of functional parameters such as vessel growth, microvascular perfusion, vascular permeability and cellular interactions.

(2) Apart from conventional epi-illumination fluorescence microscopy, imaging in the dorsal skinfold chamber model has increasingly been performed in recent years by means of confocal microscopy techniques (Isaka et al., 2004; Makale, 2007; Strieth et al., 2008, text references). Using a pinhole aperture for point illumination, single-photon laser-scanning microscopy allows the detection of light from a specific volume within the plane of focus, so that the resultant image is comparatively free of scattered light and attendant blurring (Makale, 2007). Accordingly, the obtained microscopic images exhibit an improved optical resolution and contrast. Moreover, it is possible to concatenate individual optical sections to create a three-dimensional reconstruction of the object of interest. As a variation of this technique, multiphoton microscopy uses near-infrared lasers for two-photon excitation, which allows the generation of bright, high-resolution images in sample depths of 500-1000 $\mu \mathrm{m}$, while photobleaching and phototoxicity-induced tissue damage is markedly reduced (Makale, 2007; Ishii and Ishii, 2011, text references).

In addition to microscopy, several other non-invasive techniques have been used in the past for the analysis of microcirculatory parameters within the dorsal skinfold chamber, including Laser Doppler flowmetry for the assessment of microvascular tissue perfusion (Menger et al., 1992b, text reference) or phosphorescence quenching for the measurement of tissue oxygenation (Kerger et al., 1996, text reference). However, these techniques are indirect in nature and, thus, do not allow for the direct visualisation of distinct cellular mechanisms, such as the interaction of leukocytes with the microvascular endothelium or the ingrowth of new blood vessels into implanted biomaterials.

(3) For implantation of a biomaterial, the cover glass of the chamber is temporarily removed and the biomaterial is freely positioned onto the panniculus carnosus muscle taking care to avoid contamination, mechanical irritation or damage of the prepared tissue. Due to this mode of implantation, there is no mechanical loading of the biomaterial. However, mechanical stress has been shown to be a crucial determinant for the angiogenic activation and differentiation of stem cells (Kasper et al., 2007; Glaeser et al., 2010, text references) and, thus, may in particular affect the vascularisation of stem cell-seeded biomaterials, such as scaffolds for tissue engineering (Sandino et al., 2010, text reference).

To overcome the disadvantage that the mechanical environment is completely excluded in the chamber model, static mechanical load can be applied to biomaterial implants by pressing a silicone pad, which is fixed with an 
adjustable screw to one of the chamber frames, on the cutis of the back side of the observation window (Contaldo et al., 2007, text reference). The combination of this technical modification with a micromotor may in future studies even allow exposing biomaterial implants to dynamic mechanical stresses over prolonged time periods.

Reviewer I: What is the infection rate of the animals after the implantation of the dorsal skinfold chamber?

Authors: The infection rate of the animals is rather low. In well trained hands, less than $10 \%$ of dorsal skinfold chambers show local signs of infection, i.e. vasodilation and oedema formation, after implantation. To guarantee this low infection rate, it is important to disinfect thoroughly the back of the animals and all instruments during the implantation procedure of the chamber. Moreover, the whole procedure should not exceed 20-30 min to reduce the time to a minimum, during which the prepared tissue layers within the observation window are exposed to the ambient air.

Reviewer I: Are there any cases where the animals felt much discomfort and then eventually the operation failed? Authors: The authors are not aware of such cases. As already stated in the manuscript, the animals tolerate the chambers well, as indicated by normal daily feeding, cleaning and sleeping habits, which do not differ from those of animals without chambers.

Reviewer I: Is it possible that the chamber can be used for the growth of embryonic tissues, stem cells or cancer cells? Authors: Because the cover glass of the observation window can temporarily be removed, the dorsal skinfold chamber suits ideally for transplantation and implantation experiments. Accordingly, this model has been extensively used to study the growth and vascularisation of various tumour types (Vajkoczy et al., 2000; Bingle et al., 2006; AlJamal et al., 2010, additional references), ovarian follicles (Laschke et al., 2002, additional reference), endometrial tissue (Laschke et al., 2005c, additional reference), and transplanted stem cell spheroids (Moosmann et al., 2005, additional reference).

Reviewer II: Mice, rats and hamsters have been used as the animals for the implantation of the dorsal skinfold chamber. How are these three types of animals compared when this technique is used?

Authors: The basic principle of this model, i.e. to provide a chronic access to exposed tissues in an implanted chamber for microscopic imaging through an observation window, is identical in mice, rats and hamsters. However, as already described in our article, there are minor differences between these species when applying this model. In contrast to rats and mice, preparation of the dorsal skinfold chamber in hamsters bears the major advantage that the retractor muscle is only loosely attached to the underlying panniculus carnosus muscle without many vascular interconnections between the two muscle layers. Accordingly, the retractor muscle can easily be removed without surgical trauma to the tissue, which serves for later microscopic analyses. Moreover, the hamster dorsal skinfold preparation is characterised by a better translucency due to a thinner panniculus carnosus muscle, resulting in an improved microscopic image quality when compared to the mouse or rat chamber. On the other hand, the mouse as experimental animal is less expensive and genetically better defined than the hamster. In addition, there is a multitude of knock-out and transgenic strains, which allow for the analysis of physiological and pathological processes on a molecular basis. The availability of a broad range of monoclonal antibodies directed against distinct cell surface molecules further enables for detailed immunohistochemical analyses of isolated tissue samples. For these reasons, biomaterial studies in the dorsal skinfold chamber model are increasingly performed in mice.

Reviewer II: How are the findings derived from the dorsal skinfold chamber compared with the actual clinical outcome when the biomaterials tested in animals are used in humans?

Authors: The dorsal skinfold chamber model is typically used to analyse the early angiogenic and inflammatory host tissue response to biomaterials during the first 2-3 weeks after implantation. Because biomaterials in humans are usually not analysed during the first 2 weeks after implantation, a direct comparison of the findings derived from the dorsal skinfold chamber model with the actual clinical outcome is difficult. Moreover, because in clinics materials are normally analysed only functionally, there are no systematic angiogenesis data available during the first 2 weeks. However, it has to be considered that this early observation period is of particular interest in biomaterial testing, because especially the initial vascularisation of implants has been proposed to be a crucial determinant for adequate biomaterial incorporation into the host tissue, minimising the risk of extrusion, migration and infection.

Reviewer II: Are the daily activities of the mouse with an implanted chamber affected as the metal frames look big as compared with the size of the animal?

Authors: The chamber frames are made of titanium and, thus, the entire chamber for mice exhibits a low weight of $\sim 2 \mathrm{~g}$, representing less than $10 \%$ of the body weight of the animals. Accordingly, the animals tolerate the chambers well, as indicated by normal daily activities, feeding and cleaning habits, which do not differ from those of their litter mates.

Reviewer II: In this review, this chamber is described as a chronic in vivo model. What does "chronic model" mean? Authors: In acute animal models analyses are typically performed only at a single observation time point. In contrast, the term "chronic model" means that the dorsal skinfold chamber allows for the non-invasive and repetitive analysis of the angiogenic and inflammatory host tissue response to implanted biomaterials in individual animals over an observation period of 2-3 weeks.

Reviewer II: The intravital microscopy is described as a sophisticated technique in the review, so how does it work? Authors: Intravital fluorescence microscopy can be used 
to study distinct cellular and molecular processes in the living animal with a good temporal and spatial resolution by the application of different fluorescent dyes (examples are listed in our article). Upon excitation of these dyes by light of defined wavelength, they emit photons, which are then focused to a camera detector. The camera images are recorded on DVD or hard disk for subsequent off-line analysis by means of a computer-assisted image analysis system.

Reviewer II: How do transgenic mice help with this chamber in various types of biomedical research?

Authors: During the last years, transgenic or knock-out mouse strains have gained major importance in biomedical research with the chamber model, because they provide completely new insights into the regulation of inflammatory and angiogenic processes on a molecular basis. For instance, the analysis of venular leukocyte-endothelial cell interaction in tumour necrosis factor (TNF)- $\alpha$-treated dorsal skinfold chamber preparations of mice deficient in angiopoietin (Ang)-2 could identify Ang-2 as an important autocrine regulator of endothelial cell inflammatory responses (Fiedler et al., 2006, additional reference). Moreover, intravital fluorescence microscopy of in situ prevascularised scaffolds from green fluorescent protein (GFP)-transgenic mice implanted into dorsal skinfold chambers of wild-type recipient animals has been used to study the interaction of the implants' preformed blood vessels with the host microvasculature at the implantation site (Laschke et al., 2010, 2011, text references). Based on the findings of such studies it may be possible in the future to develop novel biomaterial implants with an improved biocompatibility and vascularisation potential.

Reviewer II: In orthopaedic or traumatic studies, some bone substitutes are quite big in size. Can this chamber be used for testing the biocompatibility of these big substitutes?

Authors: For the in vivo analysis of bone substitutes in the dorsal skinfold chamber, the implants should not be thicker than $1 \mathrm{~mm}$ to guarantee the closure of the chamber free from air. Moreover, the bone substitutes should not substantially exceed a size of $\sim 3 \times 3 \mathrm{~mm}$ to enable analyses of the border zones in direct vicinity to the implants as well as of distant areas within the chamber, which may serve as control tissue that is not affected by the implants. Thus, bone substitutes, which may be quite big in size for clinical applications, cannot be tested in their original size. This, however, does not necessarily represent a disadvantage for the analysis of the angiogenic and inflammatory host tissue response at the implantation site. In fact, the testing of small biomaterial samples of identical sizes bears the advantage that the biocompatibility of these samples is directly comparable under the standardised conditions of the dorsal skinfold chamber model.

Reviewer II: Are there any possibilities where the tested biomaterials induce severe immune responses or inflammation that jeopardise the animal's survival or daily activities?
Authors: Implanted biomaterials may only induce a local but not systemic inflammatory host response. Accordingly, testing of biomaterials in the dorsal skinfold chamber model does not jeopardise the animal's survival or daily activities.

Reviewer III: To what extent has confocal microscopy been applied in the skinfold model?

Authors: In the past, most studies in the dorsal skinfold chamber model have been performed by means of epiillumination fluorescence microscopy. However, in recent years confocal microscopy techniques have increasingly gained in importance when using this model (Isaka et al., 2004; Makale, 2007; Strieth et al., 2008, text references), because the obtained microscopic images exhibit an improved optical resolution and contrast. Moreover, it is possible to concatenate individual optical sections to create a three-dimensional reconstruction of the object of interest. Finally, multiphoton laser-scanning microscopy allows the generation of bright, high-resolution images in sample depths of 500-1000 $\mu \mathrm{m}$, while photobleaching and phototoxicity-induced tissue damage is markedly reduced (Makale, 2007; Ishii and Ishii, 2011, text references).

Reviewer III: There is an emerging field of biomaterial immunology. What unique contributions may the skinfold implant make to studies in this area?

Authors: The dorsal skinfold chamber model in combination with intravital microscopy techniques offers the unique opportunity to study repetitively in vivo the dynamic inflammatory host tissue response to implanted biomaterials throughout an observation period of 2-3 weeks. For this purpose, leukocytes are stained in situ with the fluorescent dye rhodamine $6 \mathrm{G}$ to analyse their interaction with the microvascular endothelium of blood vessels at the implantation site. Moreover, activation and accumulation of mast cells around biomaterial implants can be studied by topical ruthenium red staining of the chamber tissue. Finally, distinct subsets of immune cells may be isolated and reinjected after ex vivo labelling to investigate their recruitment at the implantation site. This approach may allow an even more detailed analysis of the time-dependent contribution of different immune cell types to the foreign body reaction of the host tissue within the dorsal skinfold chamber.

\section{Additional References}

Al-Jamal KT, Al-Jamal WT, Akerman S, Podesta JE, Yilmazer A, Turton JA, Bianco A, Vargesson N, Kanthou C, Florence AT, Tozer GM, Kostarelos K (2010) Systemic antiangiogenic activity of cationic poly-L-lysine dendrimer delays tumor growth. Proc Natl Acad Sci U S A 107: 39663971.

Bingle L, Lewis CE, Corke KP, Reed MW, Brown NJ (2006) Macrophages promote angiogenesis in human breast tumour spheroids in vivo. Br J Cancer 94: 101-107. 
Fiedler U, Reiss Y, Scharpfenecker M, Grunow V, Koidl S, Thurston G, Gale NW, Witzenrath M, Rosseau S, Suttorp N, Sobke A, Herrmann M, Preissner KT, Vajkoczy P, Augustin HG (2006) Angiopoietin-2 sensitizes endothelial cells to TNF- $\alpha$ and has a crucial role in the induction of inflammation. Nat Med 12: 235-239.

Laschke MW, Menger MD, Vollmar B (2002) Ovariectomy improves neovascularization and microcirculation of freely transplanted ovarian follicles. J Endocrinol 172: 535-544.

Laschke MW, Elitzsch A, Vollmar B, Menger MD (2005c) In vivo analysis of angiogenesis in endometriosis- like lesions by intravital fluorescence microscopy. Fertil Steril 84 Suppl 2: 1199-1209.

Moosmann S, Hutter J, Moser C, Krombach F, Huss R (2005) Milieu-adopted in vitro and in vivo differentiation of mesenchymal tissues derived from different adult human CD34-negative progenitor cell clones. Cells Tissues Organs 179: 91-101.

Vajkoczy P, Menger MD, Goldbrunner R, Ge S, Fong TA, Vollmar B, Schilling L, Ullrich A, Hirth KP, Tonn JC, Schmiedek P, Rempel SA (2000) Targeting angiogenesis inhibits tumor infiltration and expression of the proinvasive protein SPARC. Int J Cancer 87: 261-268. 